\title{
The Shell Gravel Deposits, and the Infauna of the Eddystone Grounds.
}

\author{
By \\ J. E. Smith, B.Sc., \\ Student Probationer at the Plymouth Laboratory. \\ With 4 Figures in the Text.
}

THE brief survey of the Eddystone shell gravel and of its infauna, the results of which are described in this paper, was begun in January, 1931, and extended over a period of twelve months. The original object of the survey was to make comparison of the present fauna with that found by Allen (1) on this ground during the course of a series of dredgings taken over a wide area in the Plymouth and adjacent waters, and to note the extent of the change, if any, in the faunistic character of the ground. It soon became evident, however, that if the work were to be made quantitative, it would not be feasible to effect comparison, since use would have to be made of instruments other than those adopted by Allen.

The present scope of the work includes the results of an examination of the substratum in which the members of the infauna live, its constitution, development, and conservation, a short faunistic survey of the ground, and a consideration of a few factors of importance in the bionomics of a well-defined infauna community.

Much assistance has been given by Dr. Allen, and by the members of the staft of the Plymouth Laboratory, to all of whom I am deeply indebted. To Captain Lord of the s.s. Salpa, whose advice and help at sea have been of the greatest value, and to all the members of the crew, I express my grateful thanks.

\section{Methods of Collection.}

Positions of stations, a list of which is given in Table I of the Appendix (p. 272), have been determined by means of a single bearing on the Eddystone Lighthouse, and the distance as given by the Barr and Stroud Rangefinder, Type F.T. 32, with $80 \mathrm{~cm}$. base. Positions can be determined quickly and accurately with an error of about $1.5 \%$ at 3500 yards - the greatest distance of working from the Stone. It was originally 
intended to sample the fauna over the area quantitatively by means of a ${ }_{10}^{1} \frac{1}{10} \mathrm{~m}^{2}$ Petersen grab; on most occasions, however, the instrument failed to bring up any gravel owing to the insertion of large pieces of shell between the teeth. On May 20th, 1931, twelve dips resulted in only two good hauls. Without doubt the instrument works well on the finer deposits, but in order to maintain a uniform method throughout it has been found necessary to make use of the Conical Dredge fitted with a canvas bag, and with the exception of a few hauls taken with a finemeshed Naturalist's Dredge in order to define the limits of the shell gravel on the reef border, all sampling has been done with the Conical Dredge.* This type of instrument, as used in quantitative work, has been somewhat adversely criticised, and with some justification. It is worth while considering the limits within which reliable work can be accomplished with the dredge.

In the first place, the instrument is not effective in taking a sample of the epifauna of the ground. Members of the epifauna which attach themselves to shell fragments and to stones are of course captured by any instrument capable of digging into the bottom deposit, but the epifauna also includes predatory species, active enough to get out of the way of the dredge. Not a single actively moving crustacean, mollusc, or echinoderm has been taken during the course of the work. Specimens of Ebalia tuberosa, E. tumefacta, Portunus pusillus, Conilera cylindracea, and Amphioxus lanceolatus, all of which-and particularly the latter-are capable of fairly rapid movement, have been caught, but these are really members of the infauna, and are scooped up with the gravel.

With regard to the infauna, there is no indication in the scanty comparative records of any serious discrepancy in the conical dredge haul as compared with that of the grab. Ford (8) concludes, after comparing the two, " that the conical dredge is capable of taking a good sample under favourable circumstances, and will give a good idea of the general community formation." Only two grab hauls are available for comparison as a result of the present survey. Hauls 21 and 23 (Appendix, pp. 277-8) show the numbers of the various species from 1 litre of the grab samples, and may be compared with Hauls 22 and 29 respectively, taken in the same vicinity, and representing the fauna of 1 litre of gravel from the conical dredge. The numbers of individuals of the Mollusca, Echinodermata, Crustacea, Polychæta, and Nemertini, and the number of species taken in the two hauls of each type, are given for comparison below.

\footnotetext{
* Diameter of the mouth of the dredge $=1 \mathrm{ft} .6 \mathrm{in}$. Total length

Length of canvas bag
Diameter of hinder end of the dredge $=2 \mathrm{ft} .1 \mathrm{in}$.

$=2 \mathrm{ft} .10 \mathrm{in}$.
} 
Number of Individuals from 2 Litres of Gravel from Conical Dredge and Grab Hauls.

$\begin{array}{lcr} & \text { Conical Dredge. } & \text { Grab. } \\ \text { Mollusca } & 16 \cdot 0 & 15 \cdot 5 \\ \text { Echinodermata } & 18 \cdot 0 & 51 \cdot 0 \\ \text { Crustacea } & 3 \cdot 0 & 1 \cdot 0 \\ \text { Polychæta } & 8 \cdot 0 & 9 \cdot 5 \\ \text { Nemertini } & 2 \cdot 0 & 1 \cdot 5 \\ \text { Number of species taken } & 18 & 21\end{array}$

Except in the numbers of Echinocyamus pusillus, there is no suggestion of greater efficiency on the part of the grab. The most obvious and most serious objection to the use of the conical dredge in quantitative work lies in the fact that it must be hauled a considerable distance before it can be filled; at least two adverse factors are thus involved.

1. Movement over the bottom may not be smooth, an excess of the surface layer being obtained.

2. The sample collected is a general one from a large area, the grab sample being a particular one from a small area.

Before considering these two points, it would be well to indicate the approximate distance which the dredge has been made to travel during a haul of 4-5 minutes' duration. Unfortunately, during the greater part of the work the distance was not noted, but towards the end of the survey the positions of the ship at the time of shooting of the dredge, and at the time when the dredge had been pulled to a position vertically below the stern, were taken. The observations made on December 11th are given in Table 1, below.

TABLE 1.

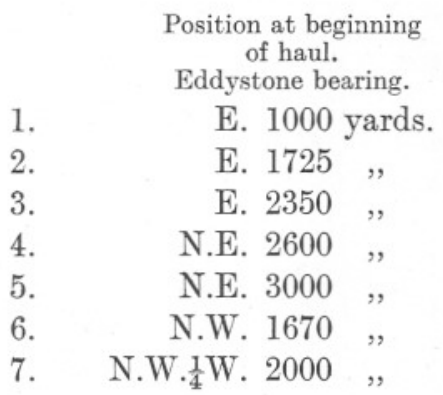

Position at end of haul.

Eddystone bearing.

E. $\frac{1}{4}$ N. 1075 yards.

E. $\frac{1}{4}$ N. 1660 ,

E. 2500 ,

N.E. $\frac{1}{4}$ E. 2720 ,

N.E. 3150 ,

N.W. 1690 ,

N.W. 2000 ,
Distance travelled by the dredge.

90 yards.

105 ,

150 ,

185 ,

150 ,

20 ,

100 , 
It is not claimed that the figures given in the last column are strictly accurate; the distances travelled by the dredge, as calculated from a consideration of the initial and final positions, are only approximate, since in the first place bearings have only been taken to the nearest $\frac{1}{4}$ point of the compass, and secondly, no allowance has been made for the error of the rangefinder. It is sufficient, however, to show that the maximum distance of hauling is about 200 yards, this maximum being attained when the ship slips away on a rapidly moving tidal stream. Hauling over this distance eliminates any possibility of detecting "patchiness" of fauna, but since the object of the survey has been rather to indicate the general nature of the fauna within arbitarily selected areas, the only danger is that in hauling over this distance more than one of such areas may have been sampled. In comparing the fauna from the different parts of the ground, difference in texture of the soil has been made the factor for division into areas, and areas differing in Representative Number* by $1 \cdot 0$ have been selected. In order to get from a gravel of Representative Number (R.N.) $x$, to one of $x+1$, or $x-1$, it is necessary to travel at least 500 yards, as reference to Figure 1 will show. Within 200 yards, gravels of R.N. difference $0 \cdot 3-0 \cdot 4$ may be sampled. There is, then, a possibility of overlapping from one area into the next, and in comparing the faunas from gravels of different texture, the R.N. must be understood to be liable to an error of the order of $\pm 0 \cdot 2$.

The probability of collecting an excess of the surface layer of the deposit, by using the conical dredge, involves

(a) The collection of a number of surface-living animals out of proportion to the number in the deeper layers of the soil.

(b) The collection of an insufficient quantity of the sub-surface gravel deposit.

The first point was considered when it was shown that there is reason to believe that the dredge is probably as efficient as any other instrument at present used in quantitative work, for obtaining a fair sample of the infauna. For the collection of a gravel sample, the grab is definitely inferior, the small amount of soil taken being exposed to the wash of the water during hauling, with the loss of a good deal of the finer particles. The middle portion of the conical dredge sample is not so exposed, and the finer grades are retained.

The routine adopted during work at sea has been as follows. When in the neighbourhood of a station selected prior to the cruise, the ship has been brought on to the required bearing relative to the Stone, and manœuvred into position, instructions as to the distance from the Eddystone, as given by the rangefinder, being given from time to time. When the

* For the explanation of the term Representative Number, and for the method of its derivation, see p. 247 . 
ship had been brought into position, the dredge was dropped over the stern on the port side, and the boat was allowed to slip away with the tide, or by giving a turn or two to the engines until 60 fathoms of warp had been paid out, when the warp was made fast. After an interval of about two minutes, hauling was commenced, and continued slowly and steadily until the dredge had just left the bottom, the final bearing and distance then being taken.

As soon as the dredge was on deck, its contents were tipped into a bath, and two bottles (of about $2 \frac{1}{2}$ litres capacity) were filled with the middle portion of the gravel, and taken back to the Laboratory ; the rest of the gravel was searched on deck in order to obtain a qualitative estimate of the fauna. From the one bottle, about $\frac{1}{2}$ litre of gravel was removed, and sieved according to Allen's method (1), whereby particles are retained on a series of sieves with circular perforations of $15.0 \mathrm{~mm}$., $5.0 \mathrm{~mm}$., $2.5 \mathrm{~mm}$., $1.5 \mathrm{~mm} ., 1.0 \mathrm{~mm}$, and $0.5 \mathrm{~mm}$. diameter, the material passing through the finest sieve being divided into two portions, one of which settles within 1 minute after stirring up with water, the other-remaining in suspension -being filtered off, dried, and weighed. After drying and weighing the remaining grades, the percentage composition of the sample was determined.* Texture has been expressed by assigning to each gravel a Representative Number, as used by Borley (4). The method of deriving the R.N. is illustrated by the analysis of a sample taken at a distance of 1725 yards W. of the Eddystone, and given below. The percentage of each grade is multiplied by the diameter of the smallest particles in that grade (i.e. the diameter of the perforations of the sieve on which the particles composing the grade are retained). Fine sand is given a diameter of $0.1 \mathrm{~mm}$., and the silt is neglected. The sum of the various products is divided by 100 , the value so obtained being the R.N. of the sample.

For quantitative estimation of the fauna, 1 litre of gravel was taken from

Very Coarse Gravel Coarse Gravel Medium Gravel Fine Gravel Coarse Sand Medium Sand Fine Sand Silt
Sieves on which particles are retained. $15.0 \mathrm{~mm}$. sieve

$5.0 \mathrm{~mm}$. ,,

$2.5 \mathrm{~mm}$. ,,

$1.5 \mathrm{~mm}$.,

$1.0 \mathrm{~mm}$. ,,

$0.5 \mathrm{~mm}$. ,

Passes through 0.5 mm. sieve

do. but in suspension

after 1 minute
A.

Grade.

$15 \cdot 0$

$5 \cdot 0$

$2 \cdot 5$

1.5

$1 \cdot 0$

0.5

$0 \cdot 1$

$0 \cdot 0$
B.

Percentage

Composition.

0.16

9-12

$37 \cdot 84$

$26 \cdot 02$

$11 \cdot 35$

$8 \cdot 13$

$5 \cdot 70$

$1 \cdot 67$

$\overline{99 \cdot 99}$
$\mathrm{A} \times \mathrm{B}$.

$2 \cdot 40$

$45 \cdot 60$

$94 \cdot 60$

$39 \cdot 03$

$11 \cdot 35$

4.06

$0 \cdot 57$

$0 \cdot 00$

$$
\text { Representative Number } \begin{aligned}
& \frac{\mathrm{A} \times \mathrm{B}}{100}=\frac{197.61}{100} \\
& =1.98
\end{aligned}
$$

$197 \cdot 61$

\footnotetext{
sieving.

* Large, living bivalves and echinoderms were removed from the sample previous to
} 
the second bottle and sieved, all living animals retained on the 15, 5, 2.5, and $1.5 \mathrm{~mm}$. sieves being picked out by searching the gravel, a little at a time, under water in shallow enamel dishes. The time and labour required for searching increases with decreasing size of particle, and the limit for all practical purposes may be set at the $1.5 \mathrm{~mm}$. grade. The importance of examining the gravel of this grade with some thoroughness may be gathered from the fact that the mollusc Astarte triangularis, which from the point of view of numbers is the most important mollusc in the shell gravel, has been found in grade 1.5 only. Small polychætes, crustacea, and nemertini were obtained by repeated shaking of the sample with water, and straining the liquid through cheese-cloth. In addition, measurements of all undamaged dead mollusc valves from grades 15, 5, 2.5, and 1.5 of the dried gravel, as used for determining the R.N., were made, and will be referred to later.

\section{The Nature of the Bottom.}

Dredging in the immediate neighbourhood of the Eddystone reveals the fact that there is a considerable area where there is little or no veneer of shell covering the bare rock. The limits of this type of ground, from which the dredge comes up empty, or with a fauna obviously associated with a solid substratum, are indicated in the chart (Fig. 1). The greater area of the bottom surrounding the Eddystone reef is covered with shell gravel, extending over an area bounded by the circumference of a circle of 3000-4000 yards radius, with the exposed reef as its centre.

Three well-marked submarine ridges run out to the N.E., S.E., and N.W. of the exposed reef, upon which the present light and the stump of the old Smeaton Tower stand. The sides of the reef slope down rapidly into about 30 fathoms of water, and Worth (in 1) notes that the summit and a portion of the sloping sides are gneissic in character, whilst triassic fragments preponderate at points more distant from the main reef.

Examination of the bottom samples taken during the course of the present work made it clear that gneiss is the main inorganic constituent of the samples taken in the immediate neighbourhood of the reef, but that sandstones and pebbles are found to the exclusion of gneiss at points no more distant from the reef than 1800 yards. No attempt has been made to separate the gneissic and triassic rocks, all of which have been included in the general term of " matter of inorganic origin." Table 2 gives the amount of such material in grammes per $1000 \mathrm{gm}$. of a sample, as selected from grades $15,5,2 \cdot 5$, and $1 \cdot 5$. The greatest quantity of inorganic matter is found,

(1) In samples taken near the exposed reef-at a distance of 1000 to 1500 yards.

(2) In samples taken at distances of 2000 yards or more from the reef. 
To the E. and N.E. of the Stone (in Table 2, as Eddystone bearing W. and S.W.), however, there is a progressive decrease up to distances of 2500 and 3500 yards, respectively, a circumstance to which reference will be made later. The first series of gravels have as their main inorganic constituent, gneiss, the second, sandstones and pebbles. Between the two series is an area, the gravels of which contain very little inorganic matter.

Unbroken and broken mollusc valves constitute the greater part of the larger fragments of the shell gravels, whilst in the lower grades, echinoid spines, polyzoan "stalks" and a few unbroken and broken mollusc valves and Echinocyamus pusillus tests are found together with sand. Altogether some 30 species of lamellibranchs are represented. Undamaged valves, echinoid tests and gastropods, have been picked out from grades 15, 5, $2 \cdot 5$, and $1 \cdot 5$, and their numbers as they occur in a series of samples are given in Table II of the Appendix.

TABLE 2.

Number of Grammes of Matter of Inorganic Origin and of Undamaged Shell Per 1000 GM. of Gravel.*

\begin{tabular}{|c|c|c|c|c|}
\hline & \multicolumn{2}{|c|}{$\begin{array}{l}\text { Position of station. } \\
\text { Eddystone bearing. }\end{array}$} & $\begin{array}{c}\text { Gm. of } \\
\text { inorganic } \\
\text { matter. }\end{array}$ & $\begin{array}{c}\text { Gm. of } \\
\text { undamaged } \\
\text { shell. }\end{array}$ \\
\hline \multirow[t]{3}{*}{ N.E. } & N.E. $\frac{1}{4}$ N. $1850 \mathrm{y}$ & yards. & $3 \cdot 62$ & $51 \cdot 50$ \\
\hline & N.E. 2600 & , & $305 \cdot 77$ & $4 \cdot 38$ \\
\hline & N.E. 3000 & , & $520 \cdot 03$ & $4 \cdot 13$ \\
\hline \multirow[t]{4}{*}{ N.W. } & N. by W. 1090 & ", & $244 \cdot 33$ & $11 \cdot 06$ \\
\hline & W.N.W. 1075 &, & $123 \cdot 30$ & $4 \cdot 51$ \\
\hline & N.W. 1670 & , & $89 \cdot 30$ & $29 \cdot 71$ \\
\hline & N.W. $\frac{1}{4}$ W. 2000 & , & $87 \cdot 99$ & $24 \cdot 56$ \\
\hline \multirow[t]{3}{*}{$W$} & W. 1075 &, & $62 \cdot 43$ & $16 \cdot 69$ \\
\hline & W. 1100 & , & $21 \cdot 87$ & $9 \cdot 07$ \\
\hline & W. 2525 &, & $0 \cdot 79$ & $5 \cdot 85$ \\
\hline \multirow[t]{3}{*}{$S . W}$. & S.W. 1700 & , & $348 \cdot 70$ & $11 \cdot 30$ \\
\hline & S.W. 2600 & , & $57 \cdot 18$ & $11 \cdot 97$ \\
\hline & S.W. 3500 & , & $23 \cdot 37$ & $6 \cdot 63$ \\
\hline \multirow[t]{3}{*}{ S.E. } & S.S.E. 1010 & , & $112 \cdot 02$ & $12 \cdot 02$ \\
\hline & S.E. by S. $\frac{1}{4}$ S. 1760 & , & $12 \cdot 00$ & $25 \cdot 02$ \\
\hline & S.S.E. 2175 & $"$ & $203 \cdot 41$ & $4 \cdot 60$ \\
\hline \multirow[t]{2}{*}{$E$. } & E. 1725 & , & $30 \cdot 00$ & $25 \cdot 28$ \\
\hline & E. 2350 & , & $513 \cdot 22$ & $6 \cdot 64$ \\
\hline
\end{tabular}

* Broken shell, polyzoan and echinoid remains, and fine sand, account for the greater part of nearly all the gravels. 
Excluding the gastropods, of which it is difficult to make an exact census, it is notable that the molluses Glycymeris glycymeris, Astarte triangularis, Gafrarium minimum, Chione ovata, Chione fasciata, and the echinoid Echinocyamus pusillus, comprise at least half the total number of undamaged, specimens, and are frequently found in such numbers as to constitute $80-90 \%$ of the whole. All the species, the shells of which have been taken in any number in the gravel, have also been taken alive either in the conical or in the naturalist's dredge. Table 2 will show that, generally speaking, the greatest aggregations of undamaged shell occur in the gravels where the inorganic matter is in the least quantity; the figures in the table represent the number of gm. of undamaged shell per $1000 \mathrm{gm}$. of gravel.

Three well-defined gravel areas are thus to be found.

(1) The Inner Shell Gravel, in which gneiss is the chief component of the inorganic material, and in which the concentration of undamaged shell is low.

(2) The Middle Shell Gravel, where very little matter of inorganic origin is to be found, and where the concentration of shell, broken and unbroken, is high.

(3) The Outer Shell Gravel, where pebbles and sandstones are found in quantity, and where undamaged shells are not found in large numbers.

The approximate limits of these areas are indicated in the chart (Fig. 1).

The Representative Number of a sample has been shown to be a measure of the degree of coarseness of a deposit, a quality determined to a very great extent by the degree of scour to which the bottom is exposed. Worth in (1), in considering samples taken in the neighbourhood of the Eddystone, notes that "with one exception the fine textures occur at some considerable distance from the reef, while the coarse textures are clustered around the reef or around the Hand Deeps."* During the course of the year a sufficient number of samples have been taken to show that essentially this is the case, as will be seen by reference to Figure 1, where the R.N.s of samples taken at various positions around the Eddystone reef are shown.

The Representative Numbers of samples taken along lines radiating from the Eddystone are given in Table 3. The figures without brackets are the R.N.s as calculated from the amounts of all types of material remaining on the various sieves. A decrease in value of the R.N. is found as the samples are taken at progressively increasing distances from the Light; in one or two instances, however-in the Outer Shell Gravel area-

* The Hand Deeps are about $4 \frac{1}{4}$ miles N.W. of the Eddystone. 


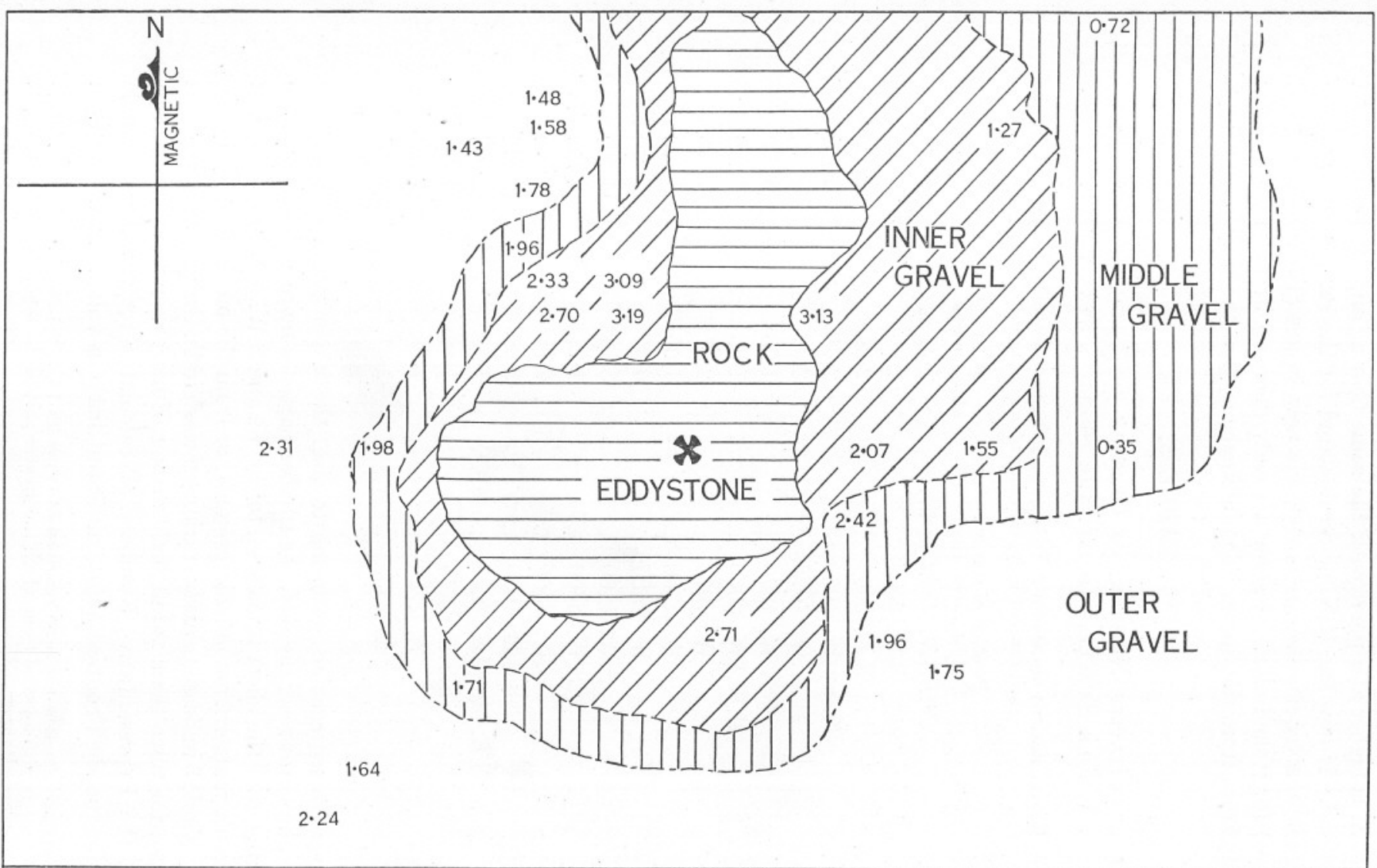

FIg. 1.-Chart showing the Representative Numbers-indicated thus, 2.42 - of the gravel samples taken round the Eddystone reef, and the approximate limits of the bare rock, and of the Inner, Middle and Outer shell gravel areas. Scale: $1 \mathrm{~cm} .=440 \mathrm{yards}$,
Area without gravel covering, shown thus
$\overline{\overline{\text { IIIIII }}}$
Middle shell gravel area, shown thus
Outer shell gravel area
unshaded 
the R.N. is higher at a point with the same bearing on, but further from the Stone. If now the R.N. be recalculated for the sample, after all the inorganic matter has been removed, the new values (Table 3, bracketed figures) for "shell alone,"* show a steady decrease in value the greater the distance from the Stone. The inference is, that the shell is showing a

\section{TABLE 3.}

\section{Representative Numbers of Gravels as Calculated for the Whole Sample and for the Shell Content only.}

(Middle Gravel stations are shown in italics, the R.N. for the whole sample, and for the shell content only, differing by less than $0 \cdot 10$.)

\begin{tabular}{|c|c|c|c|c|}
\hline & $\begin{array}{l}\text { Position of stat } \\
\text { Eddystone bear }\end{array}$ & $\begin{array}{l}\text { ion. } \\
\text { ing. }\end{array}$ & $\begin{array}{c}\text { R.N. } \\
\text { whole sample. }\end{array}$ & $\begin{array}{c}\text { R.N. } \\
\text { shell only. }\end{array}$ \\
\hline N.E. & N.E. $\frac{1}{4} N .1850$ ? & yards. & $1 \cdot 71$ & $(1 \cdot 70)$ \\
\hline & N.E. 2600 & , & $1 \cdot 64$ & $(0 \cdot 91)$ \\
\hline & N.E. 3000 & , & $2 \cdot 24$ & $(0 \cdot 74)$ \\
\hline N.W. & N. by W. 1090 & , & $2 \cdot 71$ & $(1 \cdot 89)$ \\
\hline & $W . N . W .1075$ & , & 2.42 & $(2 \cdot 35)$ \\
\hline & N.W. 1670 & , & $1 \cdot 96$ & $(1 \cdot 78)$ \\
\hline & N.W. $\frac{1}{4}$ W. 2000 & , & $1 \cdot 75$ & $(1 \cdot 65)$ \\
\hline$W$. & W. 1075 & , & $2 \cdot 07$ & $(1 \cdot 93)$ \\
\hline & W. 1700 &, & 1.55 & $(1 \cdot 42)$ \\
\hline & $W .2525$ & , & $0 \cdot 35$ & $(0 \cdot 35)$ \\
\hline S.W. & S.W. 1100 & , & $3 \cdot 14$ & $(1 \cdot 80)$ \\
\hline & S.W. 2600 & , & $1 \cdot 27$ & $(1 \cdot 17)$ \\
\hline & S.W. 3500 & , & 0.72 & $(0 \cdot 66)$ \\
\hline S.E. & S.S.E. 1010 & , & $3 \cdot 09$ & $(2 \cdot 91)$ \\
\hline & S.E. by S. $\frac{1}{4} S .1760$ &, & 1.99 & $(1.97)$ \\
\hline & S.S.E. 2175 & , & $1 \cdot 48$ & $(1 \cdot 24)$ \\
\hline$E$. & E. 1725 & , & 1.98 & $(1.92)$ \\
\hline & E. 2350 & , & $2 \cdot 31$ & $(1 \cdot 24)$ \\
\hline
\end{tabular}

progressive segregation according to size, the larger particles being the more abundant near the reef, the smaller particles more so away from the reef, but that the effect is masked, to the W. and S.W., by the intrusion of inorganic matter from outside grounds, or from the outer portions of the reef. Table 3 indicates clearly stations of the Middle Gravel area (figures in italics), for since there is but little matter of inorganic origin within this area, the Representative Numbers, as calculated for the whole sample and for the shell content alone, differ but little in value. It will be seen

* Inorganic matter has been removed from grades $15,5,2.5$ and 1.5 ; " shell alone," therefore, refers to a gravel from which the greater part of the inorganic matter has been removed. See also page 257 . 
that in the western half of the area round the Eddystone-with Eddystone bearing N.E. $\frac{1}{4}$ N., E., and S.S.E.- the Middle Gravel stations are to be found about 1800 yards distant from the main reef. To the E. and N.E., however, the Middle Gravel area is much more extensive, and is expressed most typically at stations from 3000 to 3500 yards distant (Fig. 1).

Evidence as to the extent of movement of particles over the sea floor is of a very contradictory nature. Authorities differ in opinion as to the depth at which wave action ceases to affect the equilibrium of particles lying on the sea bed, but the general opinion seems to indicate that wave action may be felt down to a depth of at least 600 feet in the open ocean $(11$, p. 80$)$. The passage of an oscillatory wave causes particles to move in an orbit perpendicular and opposite to the direction of propagation of the wave, in such a way that the particle moves back to its original position after the passage of the wave. Particles of small size and of low density will move before particles of larger diameter and of greater density, Formulæ have been developed for determining the force required to move particles of known average diameter and density, and are quoted by Borley (4), Owen (13) and others. It is sufficient, however, to realise that storm waves may lift particles from the sea floor, subsequently to be transported by currents and other agencies, with the result that there is a tendency to segregation of particles of comparable density according to size.

The direction and strength of the currents and eddies around the Eddystone reef must be variable in the extreme, and be dependent on the varying forces of wind and tide, so that it is useless to speculate on the probable resultant direction of the submarine disturbances conditioned by these forces, but it seems probable, in view of the fact that segregation takes place along lines radiating from the exposed reef, that once a particle has been raised from the floor by the passage of a wave, gravity will be the controlling factor in effecting its movement. Johnson (11, p. 208), speaking of the removal of graded cliff material from beaches, says, "the seaward inclination of the beach greatly facilitates the removal of débris into deep water; for . . . if oscillatory waves produce equal impulses alternately landward and seaward, débris on an inclined plane must travel down the slope, whereas on a horizontal bottom it might remain in one place indefinitely."

Immediately surrounding the exposed reef there is little or no covering of shell over the bare rock. In the comparatively shallow water of this region, even slight wave action will be felt, and the steep incline will assist in the passage of particles to a less disturbed and more level bottom. More distant from the Stone, the incline and depth of the bottom are sufficient to allow large pieces of shell and smaller pieces of gneiss to remain in an equilibrium position, and increasing depth associated with a 
less marked gradient will permit of the maintenance of equilibrium of smaller shells and rock fragments.

In order to show more precisely this segregation of particles according to size, the sizes of the dead valves of the commoner species of molluscs as they occur in the various gravel samples have been noted, and for this purpose measurements of all undamaged valves from grades 15, 5, 2.5 and 1.5 have been made. The average lengths of the valves of the molluscs Glycymeris glycymeris, Chione ovata, Chione fasciata, and Gafrarium minimum, and of the tests of the echinoid Echinocyamus pusillus, taken from the various samples are given in Table 4.

\section{TABLE 4.}

\begin{tabular}{|c|c|c|c|}
\hline & E. 1725 yds. & $\begin{array}{l}\text { EDDYSTONE BEARING. } \\
\text { E. } 2350 \mathrm{yds} \text {. }\end{array}$ & \\
\hline Glycymeris glycymeris & $3.91 \mathrm{~mm} . \quad(172)$ & $3.00 \mathrm{~mm} . \quad(53)$ & \\
\hline Gafrarium minimum & $3.54 \mathrm{~mm} . \quad(71)$ & $2.92 \mathrm{~mm}$. & \\
\hline Chione ovata & $3.07 \mathrm{~mm} . \quad(71)$ & $2.57 \mathrm{~mm}$. & \\
\hline Chione fasciata & $3.89 \mathrm{~mm} . \quad(39)$ & $3 \cdot 27 \mathrm{~mm}$. & \\
\hline Echinocyamus pusillus & $3.72 \mathrm{~mm}$. & $2.70 \mathrm{~mm} . \quad$ (14) & \\
\hline Chione ovata & $\begin{array}{l}\text { N.E. } \frac{1}{4} \text { N. } 1850 \text { yds. } \\
2.63 \mathrm{~mm} . \quad(175)\end{array}$ & $\begin{array}{l}\text { N.E. } 2600 \text { yds. } \\
* 3.26 \mathrm{~mm} . \quad(67)\end{array}$ & $\begin{array}{l}\text { N.E. } 3000 \text { yds. } \\
* 3.32 \text { mm. }\end{array}$ \\
\hline $\begin{array}{l}\text { Glycymeris glycymeris } \\
\text { Gafrarium minimum } \\
\text { Chione ovata } \\
\text { Chione fasciata } \\
\text { Echinocyamus pusillus }\end{array}$ & $\begin{array}{lc}\text { N. by W. } 1090 \text { yds. } \\
\begin{array}{ll}3.58 \mathrm{~mm} . & (59) \\
3.89 \mathrm{~mm} . & (65) \\
3.03 \mathrm{~mm} . & (21) \\
4.63 \mathrm{~mm} . & (27) \\
3.60 \mathrm{~mm} . & (33)\end{array}\end{array}$ & $\begin{array}{lr}\text { N.W. } 1670 \text { yds. } \\
3.43 \mathrm{~mm} . \quad(217) \\
3.50 \mathrm{~mm} . \quad(190) \\
* 3.26 \mathrm{~mm} . \quad(122) \\
4.12 \mathrm{~mm} . \quad(73) \\
3.32 \mathrm{~mm} . \quad(78)\end{array}$ & $\begin{array}{lr}\text { N.W. } \frac{1}{4} \text { W. } 2000 \text { yds. } \\
3.09 \mathrm{~mm} . & (201) \\
3.13 \mathrm{~mm} . & (139) \\
2.95 \mathrm{~mm} . & (159) \\
3.65 \mathrm{~mm} . & (93) \\
3.07 \mathrm{~mm} . & (66)\end{array}$ \\
\hline $\begin{array}{l}\text { Gafrarium minimum } \\
\text { Chione ovata }\end{array}$ & $\begin{array}{l}\text { W. } 1075 \text { yds. } \\
3 \cdot 31 \mathrm{~mm} . \quad(77) \\
2 \cdot 89 \mathrm{~mm} . \quad(59)\end{array}$ & $\begin{array}{l}\text { W. } 2525 \text { yds. } \\
2 \cdot 35 \mathrm{~mm} . \quad(28) \\
2 \cdot 44 \mathrm{~mm} . \quad(44)\end{array}$ & \\
\hline Echinocyamus pusillus & $\begin{array}{l}\text { S.W. } 1100 \text { yds. } \\
3.84 \mathrm{~mm} . \quad \text { (18) }\end{array}$ & $\begin{array}{l}\text { S.W. } 3500 \text { yds. } \\
2 \cdot 86 \mathrm{~mm} . \quad(36)\end{array}$ & \\
\hline Echinocyamus pusillus & $\begin{array}{l}\text { S.S.E. } 1010 \text { yds. } \\
3.60 \mathrm{~mm} . \quad(40)\end{array}$ & $\begin{array}{c}\text { S.E. by S. } \frac{1}{4} \text { S. } 1760 \text { yds. } \\
3.42 \mathrm{~mm} . \quad(90)\end{array}$ & \\
\hline
\end{tabular}

Measurements have been made along the anterior-posterior axes of the molluse valves, and along the oro-anal line of Echinocyamus, in each case to the nearest $\frac{1}{4} \mathrm{~mm}$. Where the range of size is great, e.g. in Chione fasciata, where all lengths from 1.5 to $20 \mathrm{~mm}$. are to be found, only those between 1.5 and $8.5 \mathrm{~mm}$. have been selected. Obviously, the same range must be adopted throughout if a true comparison is to be made. Inclusion of large valves which are probably not moved over the bottom to any extent, only obscures any variation in average size of the smaller valves, due to selective transport and segregation. The maximum limiting size of $8.5 \mathrm{~mm}$. has been chosen, because a natural break in the frequency distribution of all the valves-with the exception of Echino- 
cyamus pusillus which does not attain this length-occurs near this point ; the lower limit of $1.5 \mathrm{~mm}$. is the limit below which the possibility of picking out and counting becomes impracticable. Average length values have only been obtained where a sufficient number of valves have been measured; the numbers are given in brackets in Table 4 . With the exception of those values of average length marked with an asterisk, there is a distinct fall in average size of the valves and tests at stations taken at intervals from the reef, seawards. A possible reason for the aberrant values for Chione ovata, at stations 2600 and 3000 yards S.W. of the Eddystone, is discussed later, in the consideration of the shell gravel community.

\section{Evolution and Conservation of the Shell Gravel Bottom.}

It has been shown that the number of species contributing to the Eddystone shell gravel is not great, and that all are animals which are found alive in this particular type of deposit; the question arises as to whether this particular shell gravel area is formed from the calcareous and siliceous remains of animals which have actually lived their lives in the neighbourhood of the reef, and which have in the course of time accumulated to form the extensive deposits, or whether there has been intrusion of inorganic matter and shell, from the sea bed outside the area surrounding the sloping sides of the reef. The fact that the valves of the Abra (Syndosmya) group, and of other molluses which live in deposits other than gravel, are found only on the fringe of the muddy gravel, and then only to the extent of less than $1 \%$ of the total undamaged shell, precludes the possibility of extensive intrusion of outside forms into the gravel area. Some migration of sandstones and of pebbles probably occurs, but only into the Outer Shell Gravel deposits ; on the other hand it is not known to what extent the intruded material is derived from the outer edges of the reef.

The Outer Shell Gravel deposits are found (within the area investigated) to the S.E., S.W., W., and N.W. of the Stone, intrusion being most marked to the S.W. and W., and less so to the N.W. as is shown by the differences between the R.N.s calculated for the whole sample, and for the shell content only, of the deposits of these areas (Table 5).

TABLE 5 .

Position of station.

Eddystone bearing.

N.E. 3000 yards.

N.E. 2600 ,

E. 2350,

S.S.E. 2175 ,
R.N. whole sample.

$2 \cdot 24$

$1 \cdot 64$

$2 \cdot 31$

$1 \cdot 48$

R.N.
shell only.
$0 \cdot 74$
$0 \cdot 91$
$1 \cdot 24$
$1 \cdot 24$

R.N. whole sampleshell only.

1.50

0.73

$1 \cdot 07$

$0 \cdot 24$

It must be concluded that the outside material does not move up into the deposits found within a distance of at least 1700-1800 yards from the 
reef, a possibility much to be expected since such a movement would involve passage from a region of comparative stability, to one of more unstable equilibrium. The Inner and Middle Shell Gravel areas are thus composed of mollusc valves, polyzoan "stalks" and the like, animals which have lived on the rocky, or on the gravel ground, and dying there, have left their remains, which have become sorted out roughly according to size, during the course of which, attrition followed by removal to deeper water has taken place. The outward movement is slow but continuous, and is compensated by the continual addition of the hard skeletons of the recently dead animals.

Areas where movement and segregation are well marked have gravels with a percentage composition of the following type.

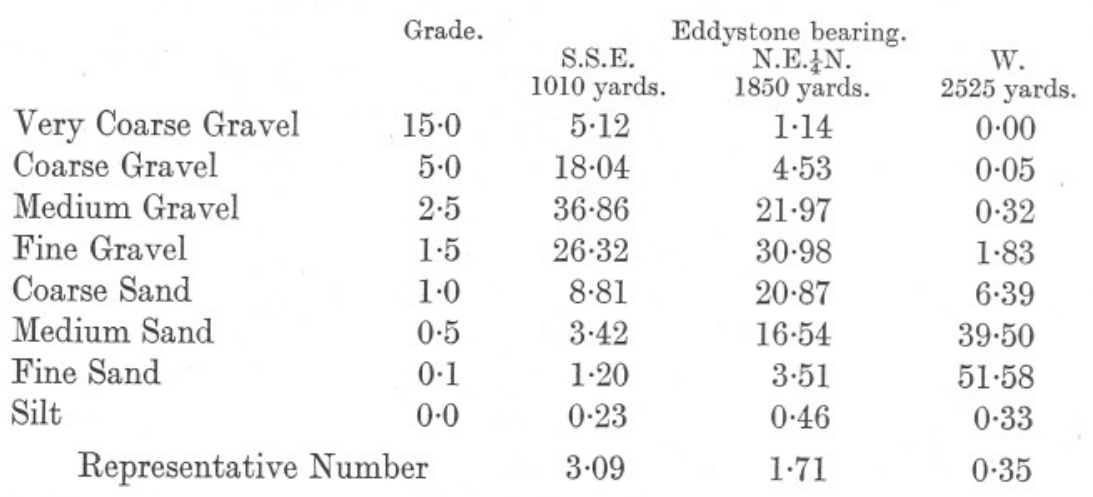

This type of deposit is characteristic of the Inner and Middle areas, inorganic matter when present, being gneissic in origin. There is a grade in which the maximum percentage of material occurs, the various amounts decreasing regularly above and below this. Such gravels will be referred to as being of the A type.

Gravels such as are found in the Outer Shell Gravel area, are of the B type, showing two maxima, one in the higher, the other in the lower grades. Their constitution is typified by the following three samples.

\begin{tabular}{|c|c|c|c|c|}
\hline Very Coarse Gravel & $15 \cdot 0$ & $\begin{array}{c}\text { E. } 2350 \text { yds. } \\
0 \cdot 30\end{array}$ & $\begin{array}{c}\text { N.E. } 3000 \text { yds. } \\
1.56\end{array}$ & $\begin{array}{c}\text { N.E. } 2600 \text { yds. } \\
1 \cdot 16\end{array}$ \\
\hline Coarse Gravel & $5 \cdot 0$ & $22 \cdot 64$ & $23 \cdot 35$ & $20 \cdot 18$ \\
\hline Medium Gravel & $2 \cdot 5$ & $29 \cdot 91$ & $20 \cdot 93$ & $13 \cdot 80$ \\
\hline Fine Gravel & 1.5 & $15 \cdot 83$ & $13 \cdot 48$ & $8 \cdot 58$ \\
\hline Coarse Sand & $1 \cdot 0$ & $8 \cdot 28$ & $6 \cdot 05$ & $6 \cdot 25$ \\
\hline Medium Sand & 0.5 & $10 \cdot 81$ & $5 \cdot 14$ & $8 \cdot 63$ \\
\hline Fine Sand & $0 \cdot 1$ & $11 \cdot 01$ & $27 \cdot 36$ & $38 \cdot 15$ \\
\hline Silt & $0 \cdot 0$ & $1 \cdot 21$ & $2 \cdot 13$ & $3 \cdot 25$ \\
\hline \multicolumn{2}{|c|}{ Representative Number } & $2 \cdot 31$ & $2 \cdot 24$ & $1 \cdot 64$ \\
\hline
\end{tabular}


Evidently the conditions under which these deposits are found, are of a much quieter nature than those giving rise to the first type, for there is present a much greater percentage of medium and of fine sand, and of silt. The large percentages of the higher grades result from the intrusion of stones from the outer grounds, for if these are removed from the grades $15,5,2.5$, and 1.5 , and the percentages recalculated, the results are as follows :-

\begin{tabular}{|c|c|c|c|c|}
\hline & Grade. & E. $2350 \mathrm{yds}$. & $\begin{array}{l}\text { Eddystone bearin } \\
\text { N.E. } 3000 \text { yds. }\end{array}$ & N.E. 2600 yds. \\
\hline Very Coarse Gravel & $15 \cdot 0$ & $0 \cdot 61$ & $0 \cdot 61$ & $1 \cdot 67$ \\
\hline Coarse Gravel & $5 \cdot 0$ & $3 \cdot 70$ & $4 \cdot 43$ & $3 \cdot 50$ \\
\hline Medium Gravel & $2 \cdot 5$ & $16 \cdot 73$ & $4 \cdot 75$ & $6 \cdot 75$ \\
\hline Fine Gravel & $1 \cdot 5$ & $16 \cdot 51$ & $4 \cdot 69$ & $6 \cdot 94$ \\
\hline Coarse Sand & $1 \cdot 0$ & $16 \cdot 51$ & $12 \cdot 74$ & $9 \cdot 00$ \\
\hline Medium Sand & 0.5 & $21 \cdot 58$ & $10 \cdot 81$ & $12 \cdot 45$ \\
\hline Fine Sand & $0 \cdot 1$ & $21 \cdot 94$ & $57 \cdot 57$ & $55 \cdot 00$ \\
\hline Silt & $0 \cdot 0$ & $2 \cdot 42$ & $4 \cdot 49$ & $4 \cdot 68$ \\
\hline \multicolumn{2}{|c|}{ Representative Number } & $1 \cdot 24$ & $0 \cdot 74$ & $0 \cdot 91$ \\
\hline
\end{tabular}

The "shell alone," from the B type gravel, is more nearly like the A type in composition, and will be referred to as the A, or shell component of the B type.

It has not been found practicable to pick out the matter of inorganic origin from grades lower than $1 \cdot 5$, so that the bracketed figures in Table 3 (p. 252), and the percentages for "shell alone" given above, do not really show the distribution of the shell in the different grades. Since, however, the greatest bulk of the inorganic matter is in the higher grades, much of the original bias is removed, although the true percentage composition of shell alone would show slightly smaller values in the grades $1 \cdot 0,0 \cdot 5$, and $0 \cdot 1$, with correspondingly larger values in grades $15,5,2 \cdot 5$, and $1 \cdot 5$. For present purposes, however, the modified R.N. will be taken as indicating the shell component of the B type gravel.

The differences between the A and B gravels are illustrated graphically in Figures 2, 3, and 4, where the divisions of the abscissæ represent the grades $5 \cdot 0,2 \cdot 5,1 \cdot 5,1 \cdot 0,0 \cdot 5$, and $0 \cdot 1$ (grade 15 , of little importance, being omitted for the sake of simplicity), and the ordinates, the percentage composition of each grade.

Figure 2 shows the single maximum of the A type gravel, which tends to be displaced to the right with decreasing submarine disturbance, and coarseness of texture. The B type (Fig. 3) has two maxima, the one on the right corresponding to the single maximum of the A type gravel, and resulting from the heaping up material segregated by tidal scour and other hydro- 


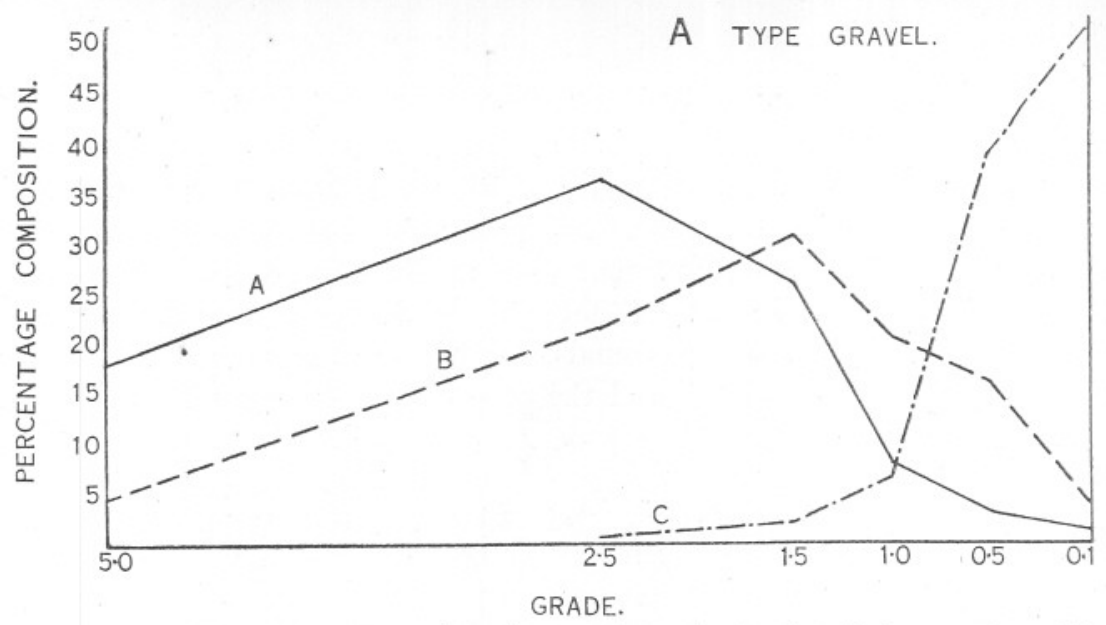

FIG. 2.-Percentage composition of the A type of gravel. A. Sample from station with Eddystone bearing S.S.E. 1010 yards. B. N.E. $\frac{1}{4}$ N. 1850 yds. C. W. 2525 yds.

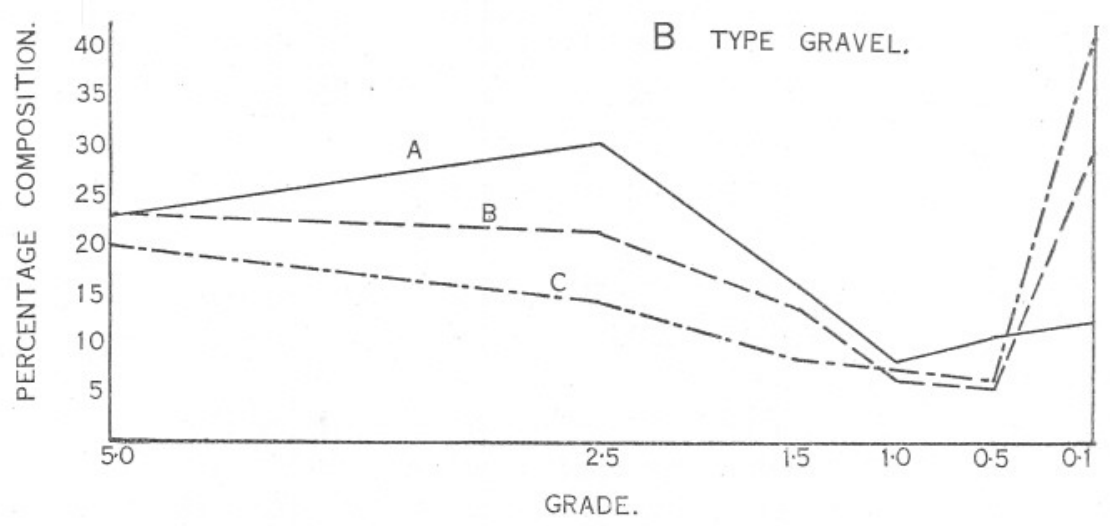

FI\%. 3.-Percentage composition of the B type of gravel. A. Sample from station with Eddystone bearing E. 2350 yards. B. N.E. 3000 yds. C. N.E. 2600 yds.

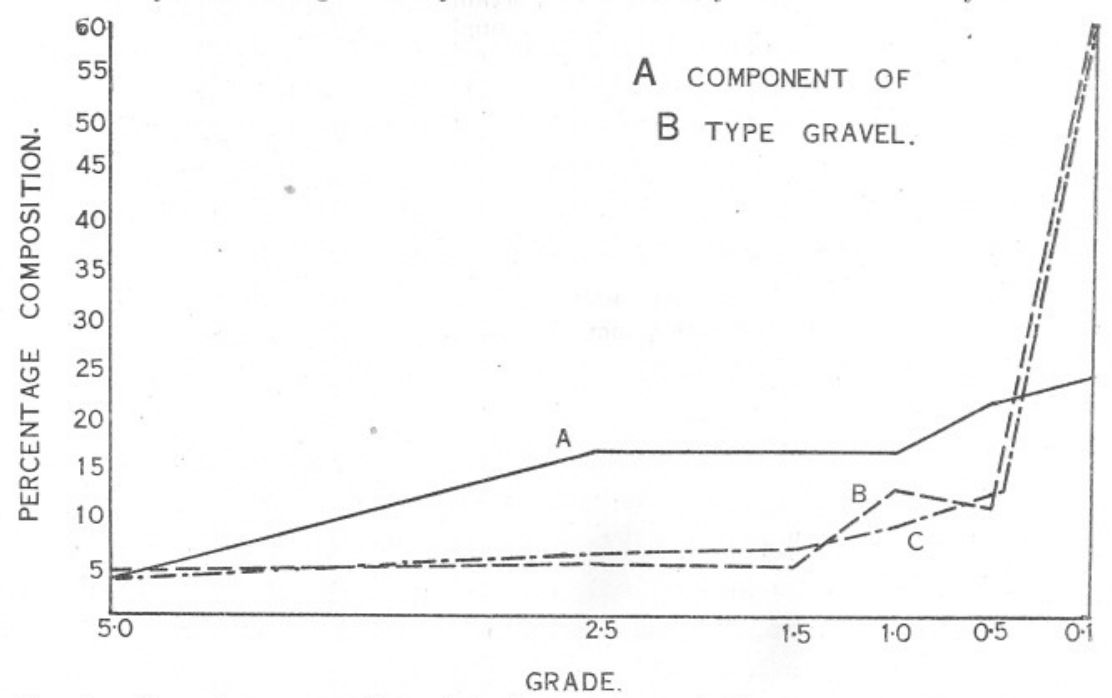

FIg. 4.-Percentage composition of the A component (shell component) of the B type of gravel. A, B and $\mathrm{C}$ represent the same three stations as in Fig. 3. 
dynamical forces, while the maximum on the left results from the introduction of outside material. The distribution of the grades of the shell component of the B type is illustrated in Figure 4, where it will be seen that the condition approaches that found in the finer of the A type gravels (Eddystone, 2525 yards W. in Fig. 2). The similarity between the shell components of the gravels at stations 2600 and 3000 yards S.W. of the Stone is at once apparent, and it appears that at a distance, at the most of 2600 yards in this quarter, the true Eddystone shell ceases to show any segregation, the increase in coarseness being due entirely to intrusion from outside. Why large fragments should be moved towards the Stone, when evidence is such as to suppose that any resultant dynamic force is in a direction away from the reef, is not clear, but it is probable that heavy swells coming in from the S.W. move the large fragments in a N.E.'ly direction, to positions where they are in equilibrium, whilst gravity combined with less severe wave action would account for the segregation of the lighter shell particles in a direction seawards from the reef.

The prevailing S.W.'ly swells, moving material in a N.E.'ly direction, are instrumental in causing, by intrusion of outside material, a reduction in area of the gravels of true Eddystone origin-gravels of the Inner and Middle areas - on the western side, whereas to the east, the tendency is towards the extension of the reef material and of shell ; there being no counterbalancing intrusion from the east, the Inner and Middle gravels are found to occupy, on this side of the Eddystone, a comparatively large area. The general characteristics of the gravels may be summarised briefly, thus :-

\section{A Type Gravel.}

Eddystone gneiss, the main constituent of inorganic origin. The percentage composition shows a single maximum. No intrusion of outside material, exhibited.

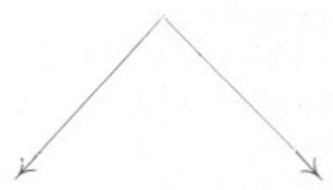

INNER SHELL GRAVEL. Gneiss in relatively large quantity.

R.N. $2 \cdot 0-3 \cdot 0$.
MIDDLE SHELL GRAVEL. Gneiss not present in any quantity.

R.N. $1 \cdot 0-2 \cdot 0$.
B Type Gravel.

Sandstones and pebbles, the main constituents of inorganic origin. The percentage composition shows two distinct maxima. Area of considerable intrusion.

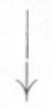

OUTER SHELL GRAVEL.

Represented only in areas of little disturbance.

R.N. relatively high.

\section{The Fauna of the Eddystone Grounds.}

\section{(a) The Fauna of the Rocky Bottom.}

At the beginning of the year, a short preliminary survey of the North and North-West quarters of the Eddystone ground was made, using a 
Naturalist's Dredge fitted with a fine-meshed net. On this side of the Stone, a considerable area of the side of the reef is devoid of a gravel covering, and has associated with it a rich attached fauna, together with an abundance of predatory species. The approximate limits of this ground are indicated in the chart (Fig. 1). It is not proposed to consider this epifaunistic community in any detail ; a list of the animals taken is given in Table III of the Appendix (p. 274). An interesting addition to the Plymouth fauna was a sponge, subsequently found by Mr. H. J. N. Borley to be a species new to science, and named by him Pseudaxinella alleni. A description of the sponge is to be found in the Journ. Mar. Biol. Assoc., N.S., Vol. XVII, No. 3, 1931. The sponge Eurypon clavatum (Bowerbank), for the identification of which I am again indebted to Mr. Borley, is also a new record for the Plymouth area.

\section{(b) The Infauna of the Shell Gravel.}

In all, 36 hauls, the positions of which are given in Table I of the Appendix (p. 272), have been taken on the gravel -9 with a Naturalist's Dredge fitted with a fine meshed net, 2 with the Petersen $\frac{1}{10} \mathrm{~m}^{2}$ grab, and 25 with the conical dredge provided with a canvas bag. Of the conical dredge hauls, 22 were examined in a quantitative manner, 1 litre of the contents of the bag being used for this purpose. For purposes of identification, the authorities quoted in the Plymouth Marine Fauna, 2nd Edition, 1931, have been consulted. Quantitative result of the hauls are listed at the end of the Appendix (pp. 274-8), and Table IV of the Appendix indicates the range of the various species over the ground, as derived from the results both of the qualitative and quantitative hauls. Grouping is made on the basis of texture of the bottom deposit ; 4 series, from deposits of R.N. greater than $3 \cdot 0$, between $2 \cdot 0$ and $3 \cdot 0$, between $1 \cdot 0$ and $2 \cdot 0$, and less than $1 \cdot 0$, being enumerated.

Excluding the incrusting polyzoa, of which only a few have been found - on stones and shells in the finer gravels - and members of the microfauna which appears on examination to be rich in small crustacea, a total of 112 species have been taken. Of these, however, 45 have been obtained once only, and only 14 species are found in any numbers-Amphioxus lanceolatus (Pallas), Glycymeris glycymeris (L.), Astarte triangularis (Montagu), Gafrarium minimum (Montagu), Chione fasciata (da Costa), Chione ovata (Pennant), Ampelisca spinipes Bœck, Conilera cylindracea (Montagu), Echinocyamus pusillus (O. F. Müller), Polygordius lacteus Schneider, Progeria remota Southern, Glycera lapidum Quatrefages, Mystides limbata de St. Joseph, and Lumbriconereis impatiens Claparède. Nowhere, however, on the gravel, are the numbers of animals comparable to those found on the more silty soils. 
Amphioxus lanceolatus (Pallas). Is fairly well distributed over the whole of the shell gravel. It is impossible to state with any degree of certainty the relative abundance of the animal on the clean and finer gravels. The method used for quantitative sampling, whilst excellent for determining the numbers of molluses and of polychætes, is of little use when applied to such an actively moving form as the lancelet. In the first place, the animal is probably able, in some degree, to evade the dredge, and secondly, whilst a bottle is being filled with a sample to be examined quantitatively, any Amphioxus which may be taken will almost certainly wriggle away and bury themselves in the larger pile of gravel which is to be searched qualitatively. The indications are, however, that Amphioxus is commoner in the coarser, than in the finer deposits. Whilst not attempting to attach any real significance to the numbers taken in each haul of the conical dredge, it is interesting to note the relative frequency of occurrence of Amphioxus in the various grades of soil, as shown below.

\begin{tabular}{lcccc}
\multicolumn{1}{c}{ R.N. of gravel. } & $>3 \cdot 0$ & $3 \cdot 0-2 \cdot 0$ & $2 \cdot 0-1 \cdot 0$ & $<1 \cdot 0$ \\
Average number of Amphioxus per haul & $11 \cdot 5$ & $8 \cdot 0$ & $5 \cdot 5$ & 0 \\
Number of hauls & 4 & 6 & 13 & $2 *$
\end{tabular}

With the exception of one of the hauls marked with an asterisk, in which very little gravel was brought up, the gravel samples, although not of equal, were of comparable volume.

Amphioxus appears to be most abundant in the gravel N.N.W. of the Eddystone-here, the scour along the bottom maintains a coarse deposit for some 2000 yards in a seaward direction-but the lancelet is likely to be found in any haul taken over a type A gravel. It will be necessary to work systematically over the B type of gravel deposit before attempting to make any estimate of the frequency of occurrence on this type of soil.

Glycymeris glycymeris (Pallas). Although this molluse has not been found in any great numbers, the number of valves in the gravel suggest that it is one of the most important of the molluscs living on the shell gravel. The records given by Allen (1), Ford (8), and Steven (22), indicate its restriction to gravel grounds, and although the numbers taken are not sufficient to justify any assertion of its distribution within the gravel area, it appears that the most consistent appearance of the mollusc is in the clean deposits.

Astarte triangularis (Montagu). Numerically, this is quite the most important mollusc found during the course of the work. In many hauls it has outnumbered the rest of the molluses put together, although its very small size $-2 \cdot 0-2 \cdot 5 \mathrm{~mm}$.- - renders it very inconspicuous. Jeffreys (10) says that it is "local but gregarious on all our coasts from the northern extremity of Shetland to the Channel Isles, in sand, at depths of from 3-60 fathoms ; it is remarkably abundant at Lewis in the Outer 
Hebrides, and at Guernsey." More recent records are not numerous; Colgan (5) records it as being common off Clare Island in 5, 10, 15, and 19 fathoms, but does not state the nature of the subsoil.

Gafrarium minimum (Montagu). Of a wide distribution, this species appears to occur mainly on gravel bottoms, but is not restricted to them. Whilst many whole valves were taken during the dredgings, it is remarkable how small a percentage contained living animals; although such is true of all the molluses found on the ground, the proportion of dead to living forms is particularly large in this species and in Chione ovata. At 8 stations at which the numbers were noted, of 95 Gafrarium examined, only 15 were alive.

Chione fasciata (da Costa). Ford (8) makes use of this mollusc (as Venus fasciata) in characterising the shell-gravel community, and contrasts the latter with the communities of the muddier deposits, where Venus gallina is the characteristic mollusc. It is only necessary to mention here that Chione fasciata has been found in fair numbers over the whole of the ground surveyed, and that the valves contribute in large numbers to the make-up of the deposit.

Chione ovata (Pennant). As with Gafrarium, the total number of living animals is small in comparison with the number of whole valves in any sample ; for the same 8 stations, of 104 whole valves, only 9 were found to contain living animals. C. ovata is not characteristic of shell gravel, but is found on a variety of bottoms. In this respect it is interesting that in the two hauls ( 46 and 47 ), taken to the S.W. of the Eddystone, where the gravels are of the B type, and contain a large proportion of silt, the valves of this mollusc are more common than are those of any other, and it is probable that the increase in average size at stations taken progressively seawards from the reef, contrary to the general direction of gradation, is due to the fact that conditions are more favourable to growth in the muddier soils, with the result that the average size is greater at death, water movement not being sufficient to transport and segregate the valves as in other quarters of the ground. If too, as we have seen, the centre of distribution of this species and of Gafrarium minimum is in a muddier soil, whilst the other common molluscs on the ground are characteristic of, and find their optimum conditions in, the shell gravel, it is not surprising that the proportion of dead to living should be higher in these species than in any of the others.

The occurrence of the polychæte Prageria remota in large numbers is worthy of notice. The genus and species were constituted by Southern, and the genotype is described by him (19). With regard to its habit, Southern says, " it is a small species, living on a bottom of sand and shells, or gravel, and would escape capture by the dredge unless special precautions were taken,... the Clew Bay specimens were obtained by 
carefully washing fine gravel." There are not enough records for one to be sure whether or not this species is restricted to bottoms of coarse texture.

Ampetisca spinipes Boeck, A. brevicornis (A. Costa), and A. tenuicornis Lilljeborg, are all found living in the shell gravel, the former in deposits of coarse texture (R.N. $>1 \cdot 0)$, whilst the latter do not appear to trespass into deposits of R.N. $>2 \cdot 0$. Between the two values of R.N. $2 \cdot 0$ and R.N. 1.0, there is a certain amount of overlapping of the two groups; Steven (22), working over the "corner" grounds, has noted a similar distinction.

Of the forms which are not true gravel dwellers, the two molluses Abra prismatica (Montagu), and Abra alba (Wood), and the polychæte Ovenia fusiformis Delle Chiaje, have been taken in the finer deposits only. The living Abras were found in the gravel 2525 yards E. of the Eddystone, at which point the maximum concentration of dead valves of these species is found.

\section{The Eddystone Shell-Gravel Community.}

The method adopted by Petersen (1\%) of naming the different animal communities by means of short terms, derived by abbreviation of the generic or specific names of the characteristic species of the communities, has the great advantage of simplicity, rendering unnecessary the listing of all the animals taken, some of which occur in small numbers only. Species which are dominant, both by number and by weight, are selected for this purpose. Seasonal animals are of little use in characterising the community, and finally, it is of practical importance to adopt for this purpose such forms as can easily be preserved and identified; and for this reason, molluscs and echinoderms are usually chosen.

Petersen laid particular stress on depth as the primary factor in determining the distribution of the nine communities found on the level sea bottom of the Danish waters- " animal communities of any water, will always be found to group themselves according to depth" (16, p. 7). The importance of the bottom deposit in this respect has however been recognised for some time by naturalists. Allen (1) has mapped out the distribution of the marine fauna over the different types of bottom, near the 30 fathom line, in the Plymouth and neighbouring waters. More recently, Ford (8), using Petersen's method of definition of the communities, has concluded that in the Plymouth area, " at least two distinct main series of level bottom animals exist alongside one another, . . . the one expressing itself in several recognisable forms in deposits in which fine grades predominate, the other being restricted to coarser soil, with its typical form restricted to clean shell gravel." Both are Venus-Spatangid associations, the former being an Echinocardium cordatum-Venus gallina (EcVg) association, the other a Spatangus purpureus-Venus fasciata (SpVf) association. The SpVf community, so characteristic of the Eddy- 
stone shell gravel, has received surprisingly little attention from marine ecologists, largely, no doubt, because most quantitative work has been done in areas where conditions are not conducive to the formation of gravel deposits. The SpVf community may be regarded as a component of Petersen's deep Venus community (v), which is apparently, as Ford (8) has pointed out, a composite association ; indeed, without any doubt, Petersen never sampled a true shell gravel deposit at any time in the Danish waters. Stephen's (21) Echinocardium cordatum-Tellina fabula (EF) community, and Spärck's (20) Mactra elliptica community, have something in common with the SpVf association, but are evidently of a composite nature.

Of the characteristic molluscs of the Eddystone shell gravel, we can speak with some degree of certainty. Variations in numbers from year to year, of the various forms, might lead successive observers to name different characteristic forms, according to the relative numbers of the different species present at the particular periods of observation, but taken over a period of years, one should be able to distinguish between those forms which are most truly characteristic, and those which are not. Such a record exists (if the hypothesis that there is little or no intrusion from outside grounds into the coarser deposits, be accepted) in the graveyard of the species - the shell deposit. Considered from the point of view of the living fauna, and with reference to their occurrence on other grounds, we should be prepared to name as characteristic the following bivalves: Glycymeris glycymeris, Chione fasciata, with a more reserved opinion regarding Astarte triangularis, Cardium scabrum, and Cardium ovale. The first three species occur in relatively large numbers over the whole of the ground, and all contribute heavily to the total of valves in the deposit. From $1800 \mathrm{gm}$. of gravel-100 gm. from each of 18 stationsAstarte triangularis is the best represented, with 760 dead valves, Glycymeris glycymeris, with 600, and Chione fasciata, with 400 . The Cardium are much less numerous-from the same 18 stations, Cardium scabrum showed 66, and Cardium ovale, 190 dead valves. Of the noncharacteristic forms, Gafrarium minimum, Chione ovata, and Echinocyamus pusillus are by far the most common, with totals of 560, 530, and 330 respectively. The numbers of valves in the gravel do not of course give an absolute measure of the relative abundance of the various species in the gravel over a period of years, since the shells of some will be able to withstand attrition for a longer period than will others, but the overwhelming numbers of valves in the gravel of those species found alive in any numbers, enables us to point out more easily the characteristic species.

Of the Archiannelids and Polychætes, there is no such past record, but it is evident that with the exception of Polygordius lacteus, and possibly Prageria remota, none are entirely confined to the shell gravel, some indeed, 
such as Nephthys hombergi and Glycera lapidum, have a wide distribution, both geographical and with relation to the bottom deposit.

The distribution of the species over the whole area is such as to suggest that any one of the three lamellibranchs, Glycymeris glycymeris, Chione fasciata, and Astarte triangularis, associated with Spatangus purpureuswhich although few in numbers, is characteristic of the ground-is sufficient to characterise the community. The polychætes are less important in this respect, since they are for the most part ubiquitous species, but the presence of Owenia fusiformis, together with the substitution of Ampelisca brevicornis and A.tenuicornis in the finer gravels, for Ampelisca spinipes of the coarser deposits, indicates the possible necessity of creating subcommunities of the SpVf association, although at this stage such a division would be unjustified. It is hoped in the near future to work along lines radiating from the Eddystone into the transition areas, in order to determine more precisely the limits of distribution of these and other species.

\section{Environmental Conditions in the Shell Gravel.}

Within a very small area where conditions of light, temperature, and salinity are almost constant, the most important limiting environmental conditions are related to

(1) The nature of the bottom, its texture and stability.

(2) The availability of the food supply.

The texture and stability of the gravel bottom has been considered in some detail, and it has been shown that the gravel, lying as it does as a covering over the solid sea floor, does not provide the stable base required by animals which attach themselves at an early stage to the substratum, and remain attached for the period of their adult lives. The abundance of hydroids, sponges, and cirripedes, on the sides of the Eddystone reef, show that it is not the inability of the larvæ to attach themselves, owing to the turbulent water conditions, that limits the distribution of the adults to quieter regions, but rather that the excessive movement of the bottom during stormy periods causes irreparable damage to the adults. The attached epifauna of the gravel is accordingly very scanty, and is practically absent from the Inner Gravel region. More removed from the main centre of disturbance, Sarcodictyon catenata, Alcyonium digitatum and a few hydroid zoophytes such as Sertularella gayi and Nemertesia antennina are to be found, but not in any quantity.

The extent of water movement also determines the amount of detritus and fine matter a gravel can hold. Without referring to the burrowing ability of the animals composing the infauna, it is of interest to note the feeding habits of the leading species; the commonest species are listed in Table 6 below, according to their mode of feeding. 


\section{TABLE 6.}

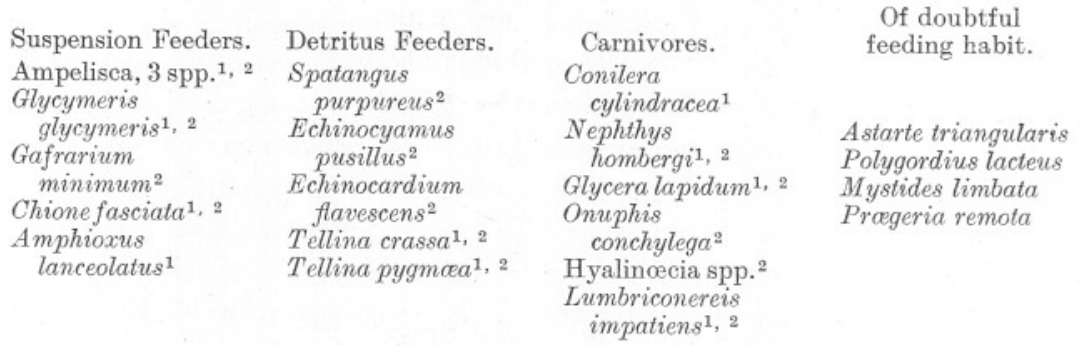

Those animals, the stomachs of which have been examined during the course of the work, are marked thus, ${ }^{1}$, otherwise the authority is that of Hunt (9), indicated thus, ${ }^{2}$. It is interesting to find that the typical gravel forms are suspension feeders, whilst the common detritus feeders and carnivores are species which, with the exception of Spatangus purpureus, are represented on other grounds, an observation much to be expected, since one would expect to find suspension feeders more typically on a ground where the bottom is constantly stirred up, than in a deposit where the food supply lies mainly in the microfauna associated with the finer grades of the deposit.

\section{Mortality among the Bivalves, and the Depredations of NATICA ALDERI.}

Mortality among the shell gravel molluses, if we are to judge by the frequency of occurrence of the dead valves in the deposit, is heaviest, as might be expected, in the younger stages. Obviously, it would be useless to plot the frequency of the different sizes, and point to the maxima as representing periods of greatest mortality, for it has been shown that in the coarser deposits small valves are washed away to regions of less disturbance. Even so, the maximum is below a size of $4.5 \mathrm{~mm}$. at all positions on the ground. Death is due to a variety of causes, either to starvation, or to being eaten by fish or other carnivores, or perhaps in the younger stages to mechanical injury caused by the shifting bottom. The only cause of which there is any measure, is that due to the gastropod Natica alderi. Here, as Davis (6) has shown, there is a means of evaluation. Natica bores through one of the valves of a lamellibranch, and after feeding on the soft tissues of the animal, leaves the two valves, which in the course of time separate and are added to the deposit. By counting all the bored valves of a species and pairing off with an equal number of unbored valves, the number of bivalves killed by Natica is obtained. Half the remaining number of single valves represents the number which have met their death in other ways, probably by starvation, since those eaten by fish are crushed and cannot subsequently be identified. 
Table 7 gives the numbers of 9 species of lamellibranchs (taken from 26 stations) bored by Natica, and of those which have met their death in other ways. Of the 9 species, the ratio of

molluscs killed by Natica

\section{molluses killed by agencies other than Natica or fish}

is greatest with the little Astarte triangularis, and least with Cardium ovale. No particular preference of the gastropod for the larger forms is to be seen, and there is no constant size preference within a single species. The mortality is much lower than on the Spisula beds in the North Sea, where Davis (6) found on one occasion a mortality as great as $88 \%$, but the conditions on the Eddystone grounds are very different. The concentration of lamellibranchs is very low, and the distribution is probably not so patchy as on the Spisula beds ; consequently, any invasion of Natica would be less disastrous in its results. The depredations are, however, sufficiently far-reaching to be of great importance in the economy of the community.

\begin{tabular}{|c|c|c|c|c|}
\hline Glycymeris glycymeris & $\begin{array}{c}\text { Size. } \\
>15.0 \mathrm{~mm} . \\
5.0-15.0 \mathrm{~mm} . \\
2.5-5.0 \mathrm{~mm} . \\
1.5-2.5 \mathrm{~mm} .\end{array}$ & $\begin{array}{c}\text { Total } \\
\text { Bivalves } \\
\text { Bored by } \\
\text { Natica. } \\
0 \\
25 \\
171 \\
33\end{array}$ & $\begin{array}{c}\text { Total } \\
\text { Bivalves } \\
\text { Unbored. } \\
5 \\
156 \\
545 \\
130\end{array}$ & $\begin{array}{c}\left.\begin{array}{c}\text { Percentage } \\
\text { Bored. } \\
0 \cdot 0 \\
13 \cdot 8 \\
23 \cdot 9 \\
20 \cdot 3\end{array}\right\} 21 \cdot 5 \\
\end{array}$ \\
\hline Astarte triangularis & $1.5-2.5 \mathrm{~mm}$ & 248 & 267 & $48 \cdot 2 \quad 48 \cdot 2$ \\
\hline Gafrarium minimum & $\begin{array}{l}5 \cdot 0-15 \cdot 0 \mathrm{~mm} \\
2 \cdot 5-5 \cdot 0 \mathrm{~mm} \\
1 \cdot 5-2 \cdot 5 \mathrm{~mm}\end{array}$ & $\begin{array}{l}30 \\
81 \\
28\end{array}$ & $\begin{array}{l}120 \\
529 \\
143\end{array}$ & $\left.\begin{array}{l}20 \cdot 0 \\
13 \cdot 3 \\
16 \cdot 4\end{array}\right\} 14 \cdot 9$ \\
\hline Chione ovata & $\begin{array}{l}5 \cdot 0-15 \cdot 0 \mathrm{~mm} \\
2 \cdot 5-5 \cdot 0 \mathrm{~mm} \\
1 \cdot 5-2 \cdot 5 \mathrm{~mm}\end{array}$ & $\begin{array}{r}21 \\
122 \\
34\end{array}$ & $\begin{array}{r}72 \\
392 \\
205\end{array}$ & $\left.\begin{array}{l}22 \cdot 6 \\
23 \cdot 7 \\
14 \cdot 2\end{array}\right\} 20 \cdot 9$ \\
\hline Chione fasciata & $\begin{array}{l}>15.0 \mathrm{~mm} . \\
5.0-15.0 \mathrm{~mm} . \\
2.5-5.0 \mathrm{~mm} . \\
1.5-2.5 \mathrm{~mm} .\end{array}$ & $\begin{array}{r}0 \\
63 \\
143 \\
21\end{array}$ & $\begin{array}{r}2 \\
62 \\
301 \\
99\end{array}$ & $\left.\begin{array}{r}0 \cdot 0 \\
50 \cdot 4 \\
32 \cdot 2 \\
17 \cdot 5\end{array}\right\} 32 \cdot 8$ \\
\hline Cardium ovale & $\begin{array}{l}5 \cdot 0-15 \cdot 0 \mathrm{~mm} \\
2 \cdot 5-5 \cdot 0 \mathrm{~mm} \\
1.5-2.5 \mathrm{~mm}\end{array}$ & $\begin{array}{r}2 \\
20 \\
3\end{array}$ & $\begin{array}{r}2 \\
250 \\
69\end{array}$ & $\left.\begin{array}{r}50 \cdot 0 \\
7 \cdot 4 \\
4 \cdot 2\end{array}\right\} 7 \cdot 2$ \\
\hline Cardium scabrum & $\begin{array}{l}5 \cdot 0-15 \cdot 0 \mathrm{~mm} \\
2 \cdot 5-5 \cdot 0 \mathrm{~mm} \\
1 \cdot 5-2.5 \mathrm{~mm}\end{array}$ & $\begin{array}{r}7 \\
20 \\
5\end{array}$ & $\begin{array}{l}29 \\
73 \\
19\end{array}$ & $\left.\begin{array}{l}19 \cdot 4 \\
21 \cdot 5 \\
20 \cdot 8\end{array}\right\} 20 \cdot 9$ \\
\hline Pseudamussium similis & $\begin{array}{l}5 \cdot 0-15.0 \mathrm{~mm} \\
2 \cdot 5-5.0 \mathrm{~mm} \\
1.5-2.5 \mathrm{~mm}\end{array}$ & $\begin{array}{r}24 \\
88 \\
0\end{array}$ & $\begin{array}{r}37 \\
286 \\
3\end{array}$ & $\left.\begin{array}{r}39 \cdot 3 \\
23 \cdot 5 \\
0 \cdot 0\end{array}\right\} 25 \cdot 6$ \\
\hline Nucula spp. & $\begin{array}{l}5 \cdot 0-15.0 \mathrm{~mm} \\
2.5-5.0 \mathrm{~mm} \\
1.5-2.5 \mathrm{~mm}\end{array}$ & $\begin{array}{r}5 \\
15 \\
0\end{array}$ & $\begin{array}{r}22 \\
70 \\
7\end{array}$ & $\left.\begin{array}{r}18 \cdot 5 \\
17 \cdot 6 \\
0 \cdot 0\end{array}\right\} 16 \cdot 8$ \\
\hline
\end{tabular}




\section{SUMMARY.}

1. The limitations of the Conical Dredge as used in obtaining a sample for quantitative estimation of the fauna of a ground are discussed, and are found to be related to

(a) The great distance over which the instrument must be hauled, with consequent inability to detect patchiness of fauna.

(b) The inability of the dredge to capture members of the epifauna.

2. The nature of the shell gravel, its position relative to the Eddystone reef, and the various factors conditioning the degree of coarseness of the deposit and the segregation of its elements are considered. The main points of note are,

(a) There are three well-defined areas, within which the gravels have their own particular characteristics.

(1) The Inner Shell Gravel area and the Middle Gravel area, composed of material of inorganic and organic origin, the former being gneissic in character, and the latter being formed of the remains of animals which normally live on this particular type of deposit.

(2) The Outer Shell Gravel area, a mixture of matter of local and of outside origin. The area is more extensive on the western than on the eastern side of the reef.

(b) Segregation of particles according to size occurs, and is illustrated by the movement of the valves of a number of species of molluses. Wave action and the action of gravity are considered to be the chief factors in inducing movement of particles, which movement occurs in directions radiating from the reef outwards.

3. The epifauna of the rocky bottom is referred to briefly.

4. The infauna of the shell gravel has been examined quantitatively and qualitatively, and the range of the various species over the ground notod.

5. The nature of the shell-gravel community and its relation to some of the important environmental factors, are discussed.

6. Mortality among the lamellibranchs, and the depredations of the gastropod Natica alderi are considered; figures relating to the numbers of lamellibranchs killed by $N$. alderi are given. 


\section{LITERATURE CITED.}

1. Allen, E. J. The Fauna and Bottom Deposits near the 30 -fathom line from the Eddystone Grounds to Start Point. Journ. Mar. Biol. Assoc., N.S., Vol. V, 1897-99.

2. Blegvad, H. Food and Conditions of Nourishment among the Communities of Invertebrate Animals found on or in the sea bottom in Danish waters. Rep. Dan. Biol. Stat., Vol. XXII, 1914.

3. Blegvad, H. Quantitative Investigations of Bottom Invertebrates in the Kattegat with special reference to Plaice Food. Rep. Dan. Biol. Stat., Vol. XXVI, 1930.

4. Borley, J. O. The Marine Deposits of the Southern North Sea. Fish. Invest., Ser. II, Vol. IV (6), 1923.

5. Colgan, N. Marine Mollusca. Clare Island Survey. Proc. Roy. Irish. Acad., Vol. XXXI-II, Section 2, Part 22.

6. Davis, F. M. Quantitative Studies on the Fauna of the Sea Bottom. No. 1. Preliminary Investigation of the Dogger Bank Fish. Invest., Ser. II, Vol. VI, No. 2, 1923.

7. Davis, F. M. Quantitative Studies on the Fauna of the Sea Bottom. No. 2. Results of the Investigations in the Southern North Sea. 1921-24. Fish Invest., Ser. II, Vol. VIII, No. 4, 1925.

8. Ford, E. Animal Communities of the Level Sea Bottom in the Waters adjacent to Plymouth. Journ. Mar. Biol. Assoc., N.S., Vol. XIII, No. 1, 1924.

9. Hunt, O. D. The Food of the Bottom Fauna of the Plymouth Fishing Grounds. Journ. Mar. Biol. Assoc., N.S., Vol. XIII, No. 3, 1925.

10. Jefrereys, G. British Conchology. Vol. II, 1863.

11. Johnson, D. W. Shore Processes and Shoreline Development. New York, 1919.

12. Monro, C. C. A. Polychæte Worms. Discovery Reports, 2, pp. 1222,1930 .

13. Owen, J. S. Experiments on the Transporting Powers of Sea Currents. Geog. Journ., April, 1908.

14. Petersen, C. G. J., and Boysen Jensen, P. Valuation of the Sea. I. Animal Life of the Sea Bottom, its Food and Quantity. Rep. Dan. Biol. Stat., Vol. XX, 1911. 
15. Petersen, C. G. J., and Boysen Jensen, P. Valuation of the Sea. II. The Animal Communities of the Sea Bottom and their Importance for Marine Zoogeography. Rep. Dan. Biol. Stat., Vol. XXI, 1913.

16. Petersen, C. G. J. On the Animal Communities of the Sea Bottom in the Skagerak, the Christiania Fjord and the Danish Waters. Rep. Dan. Biol. Stat., Vol. XXIII, 1915.

17. Petersen, C. G. J. A Survey of the work done in connection with the Valuation of the Danish Waters from 1883-1917. Rep. Dan. Biol. Stat., Vol. XXV, 1918.

18. Plymouth Marine Fauna. Second Edition, 1931.

19. Southern, R. Archiannelida and Polychæta. Clare Island Survey. Proc. Roy. Irish. Acad., Vol. XXXI-II, Section 2, Part 47.

20. Spärck, R. Preliminary Survey of the Results of Quantitative Bottom Investigations in Iceland and Faroe Waters. 1926-27. Rapp. et Proc. Verb., Vol. LVII, 1929.

21. Stephen, A. C. Preliminary Survey of Seottish waters of the North Sea by the Petersen Grab. Fish. Scot. Sci. Invest., No. 3, 1922.

22. Steven, G. A. Bottom Fauna and the Food of Fishes. Journ. Mar. Biol. Assoc., N.S., Vol. XVI, No. 3, 1930.

\section{APPENDIX.}

TABLE I. List of hauls taken during the year 1931, with bearings on, and distance from the Eddystone, of the selected stations. Representative Numbers of gravel samples are given.

TABLE II. The numbers of the various undamaged shell components of $100 \mathrm{gm}$. of each of 18 gravel samples are tabulated, and show that

(1) Of the lamellibranchs, Glycymeris glycymeris, Astarte triangularis, Gafrarium minimum, Chione ovata, and Chione fasciata, are by far the most important as regards numbers.

(2) The samples from the Middle Gravel area contain the greatest number of undamaged valves. The positions of the stations from which the samples referred to in the table are drawn, are given below. Bearings of the Eddystone are given.

Outer Gravel area
stations.
43. $\quad$ E. 2350 yards.
27. S.S.E. $2175,$,
44. N.W. $1670,$,
45. N.W. $\frac{1}{4}$ W. $2000,$,
46. N.E. $2600,$,
47. N.E. $3000,$,

\begin{tabular}{|c|c|c|}
\hline \multicolumn{3}{|c|}{$\begin{array}{l}\text { Middle Gravel area } \\
\text { stations. }\end{array}$} \\
\hline $\begin{array}{l}42 . \\
30\end{array}$ & $\begin{array}{l}\text { E. } 1725 \text { y } \\
\text { E. by S. } \frac{1}{4} \text { S. }\end{array}$ & yards. \\
\hline & $\begin{array}{l}1760 \\
3500\end{array}$ & $"$ \\
\hline & W. 2525 & ", \\
\hline & W. 1075 & \\
\hline & $\frac{1}{4}$ N. 1850 & , \\
\hline
\end{tabular}
Inner Gravel area stations.
28. S.S.E. 1010 yards.
38. S.W. 1100 ,,
36. S.W. 2600 ,",
33. W. 1075 ,
37. W. 1700 ,,
40. N. by W. 1090 ,,

39. W.N.W. 1075 , 
TABLE III. A list of the species taken from the rocky bottom N.-N.W. of the Eddystone, showing the abundance and variety of the attached forms, in marked contrast to the condition on the gravel bottom where the attached epifauna is scarcely represented.

TABLE IV. The range of the species found living in gravel is shown (Nemertini and Polyzoa excluded). Probably the only significant limitations of distribution are,

(1) Ampelisca spinipes to gravels of coarse texture, as contrasted with $A$. tenuicornis and $A$. brevicornis in the finer deposits.

(2) Owenia fusiformis which, although present in the finer deposits, is absent from the more typical shell-gravel grounds.

The list of quantitative hauls includes 22 hauls from which 1 litre of gravel from the conical dredge has been searched quantitatively, and 2 grab hauls, from which also 1 litre of gravel has been taken. 


\section{TABLE I.}

\section{List of Hauls.}

\begin{tabular}{|c|c|c|c|c|c|c|}
\hline $\begin{array}{l}\text { Date. } \\
1931 .\end{array}$ & $\begin{array}{l}\text { No. of } \\
\text { Haul. }\end{array}$ & $\begin{array}{l}\text { Bearing on, a } \\
\text { distance from, } \\
\text { Eddystone Lig }\end{array}$ & $\begin{array}{l}\text { nd } \\
\text { the } \\
\text { ght. }\end{array}$ & $\begin{array}{l}\text { Instrument } \\
\text { of capture. } \\
\text { C.D.= Coni- } \\
\text { cal Dredge. } \\
\text { D.= Natural- } \\
\text { ist's Dredge. } \\
\mathrm{G}=\frac{1}{10} \mathrm{~m}^{2} \text { grab. }\end{array}$ & $\begin{array}{l}\text { Nature of } \\
\text { ground. } \\
\text { R.= Rock. } \\
\text { G.= Gravel. } \\
\text { Rgh. }= \\
\text { Rough. }\end{array}$ & $\begin{array}{l}\text { Bottom } \\
\text { sample } \\
\text { examined } \\
\text { for } \\
\text { texture. } \\
\text { (S.) R.N. } \\
\text { given. }\end{array}$ \\
\hline \multirow[t]{6}{*}{ Jan. 21st } & 1 & S.E. $\frac{1}{4}$ S. $1225 \mathrm{y}$ & yards. & D. & G. & \\
\hline & 2 & S.E.1.S. 1625 & , & D. & G. & \\
\hline & 3 & S.E. $\frac{3}{4}$ S. 2000 & , & D. & G. & \\
\hline & 4 & S. 1175 & . & D. & R. & \\
\hline & 5 & S. by W. 1300 & , & D. & R. & \\
\hline & 6 & S. 2100 & 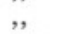 & D. & R. & \\
\hline \multirow[t]{8}{*}{ Feb. 2nd } & 7 & S. $\frac{1}{4}$ E. 2420 &, & D. & R. & \\
\hline & 8 & S.S.W. 1300 &, & D. & R. & \\
\hline & 9 & S.S.W. 1300 & , , & D. & R. & \\
\hline & 10 & S.W. 1100 &, & D. & R. & \\
\hline & 11 & S.E. by S. 1700 & ,, & D. & G. & \\
\hline & 12 & S.E. $\frac{1}{4}$ S. 1800 & ,, & D. & G. & \\
\hline & 13 & S. 680 & , & D. & R. & \\
\hline & 14 & S. $\quad 590$ & , & D. & R. & \\
\hline \multirow{4}{*}{ Feb. 16th } & 15 & S.S.E. 2600 & , & D. & G. & \\
\hline & 16 & S.S.E. 1965 & , & D. & G. & \\
\hline & 17 & S.S.E. 1760 & ," & D. & G. & \\
\hline & 18 & S.S.E. 1325 & , , & D. & G. & \\
\hline \multirow[t]{6}{*}{ May 20th } & 19 & S.S.E. 820 & ," & C.D. & G. & S. $3 \cdot 19$ \\
\hline & $19(\mathrm{a}$ & S.S.E. 640 & ,, & C.D. & R. & \\
\hline & 20 & S.E. $\frac{3}{4}$ S. 2150 & , & C.D. & G. & S. $1 \cdot 43$ \\
\hline & 21 & S.E. by S. 1320 & ,, & G. & G. & \\
\hline & 22 & S.E. by S. 1720 & , & C.D. & G. & S. 1.78 \\
\hline & 23 & S.E. $\frac{1}{2}$ S. 1920 & , , & G. & G. & \\
\hline \multirow[t]{3}{*}{ May lst } & 24 & S.E. $\frac{1}{2} \mathrm{~S} .1260$ & ,, & C.D. & G. & S. $2 \cdot 33$ \\
\hline & 25 & S.E. $\frac{1}{4}$ S. 1030 & , & C.D. & G. & S. $2 \cdot 70$ \\
\hline & 26 & S.E. $\frac{1}{2}$ S. 1500 & ," & C.D. & G. & S. 1.96 \\
\hline \multirow[t]{2}{*}{ July 23rd } & 27 & S.S.E. 2175 & , & C.D. & G. & S. $1 \cdot 48$ \\
\hline & $27(\mathrm{a})$ & $\begin{array}{l}\text { S.S.E. } 2025 \\
\text { S.S.E. } 1010\end{array}$ & , & C.D. & Rgh. & \\
\hline Sept. 3rd & $\begin{array}{l}20 \\
29\end{array}$ & $\begin{array}{l}\text { S.S.E. } 1010 \\
\text { S.S.E. } 2000\end{array}$ & "’ & C.D. & G. & $\begin{array}{l}\text { S. } 3.09 \\
\text { S } 1.58\end{array}$ \\
\hline Sept. 10th & 30 & S.E. by S.1S. 1760 & "’ & CD. & G. & S. 1.09 \\
\hline \multirow[t]{2}{*}{ Oct. lst } & 33 & W. 1075 &, & C.D. & G. & S. $2 \cdot 07$ \\
\hline & 34 & W. 2525 & , & C.D. & G. & S. $0 \cdot 35$ \\
\hline \multirow[t]{3}{*}{ Oct. 15th } & 35 & S.W. 3500 & , , & C.D. & G. & S. $0 \cdot 72$ \\
\hline & 36 & S.W. 2600 & ," & C.D. & G. & S. $1 \cdot 27$ \\
\hline & 37 & W. 1700 & ,, & C.D. & G. & S. $1 \cdot 55$ \\
\hline \multirow[t]{5}{*}{ Oct. 29th } & 38 & S.W. 1100 & , , & C.D. & G. & S. $3 \cdot 14$ \\
\hline & $38(a)$ & S.W. $\quad 850$ & , & C.D. & R. & \\
\hline & 39 & W.N.W. 1075 &,, & C.D. & G. & S. $2 \cdot 42$ \\
\hline & 40 & N. by W. 1090 &, & C.D. & G. & S. $2 \cdot 71$ \\
\hline & $40(a)$ & N.E. by N. $\frac{1}{2}$ N. 1175 & , & C.D. & R. & \\
\hline \multirow[t]{3}{*}{ Dec. 9th } & 41 & N.E. $\frac{1}{4}$ N. 1850 & , & C.D. & G. & S. $1 \cdot 71$ \\
\hline & $41(a)$ & N.E. $\frac{1}{4}$ N. 1090 & ," & C.D. & R. & \\
\hline & $41(b)$ & N.E. 2800 & , & C.D. & Rgh. & \\
\hline \multirow{8}{*}{ Dec. 11th } & 42 & E. 1725 &,, & C.D. & G. & S. 1.98 \\
\hline & 42 (a) & E. 1000 & , & C.D. & R. & \\
\hline & $42(\mathrm{~b})$ & E. 1525 & , & C.D. & R. & \\
\hline & 43 & E. 2350 & , & C.D. & G. & S. $2 \cdot 31$ \\
\hline & 44 & N.W. 1670 & ," & C.D. & G. & S. $1 \cdot 96$ \\
\hline & 45 & N.W. $\frac{1}{4} W \cdot 2000$ & ," & C.D. & G. & S. $1 \cdot 75$ \\
\hline & 46 & N.E. 2600 & ," & C.D. & G. & S. $1 \cdot 64$ \\
\hline & 47 & N.E. 3000 & , & C.D. & G. & S. $2 \cdot 24$ \\
\hline
\end{tabular}




\section{TABLE II}

Numbers of Mollusc Valves and Echinocyamus Tests (Per 100 gm. of gravel).

Nucula spp,

Anomia spp.

Monia sp.

Arca tetragona

Arca lactea

Glycymeris glyeymeri

Gravel number (See Table I for positions).

Modiolus phaseolinus

Pecten spp.

Pseudamussium similis

Lima subauriculata

$\begin{array}{rrrrrrrrrrrr}42 & 43 & 28 & 30 & 27 & 38 & 36 & 35 & 33 & 37 & 34 & 40 \\ 1 & & 1 & 1 & 2 & 3 & 5 & 2 & 2 & 2 & 1 \\ & 1 & & & & 4 & 17 & 5 & 20 & 6 & 3 \\ & & & & & & & & & & \\ 1 & & & 1 & & 1 & & & & & \\ 13 & 12 & 4 & 15 & 1 & 4 & 6 & 5 & 5 & 7 & & \\ 75 & 21 & 21 & 75 & 8 & 8 & 16 & 17 & 6 & 13 & 4 & 1 \\ & & & & & 4 & 4 & 1 & 5 & 6 & 2 & \\ 1 & 5 & 2 & 2 & & & 5 & 5 & 2 & 1 & 1 \\ 3 & 4 & 3 & 12 & 10 & & 23 & 22 & 1 & 1 & 9 \\ 1 & 1 & & & & & 3 & 1 & 1 & & 3 \\ 15 & 3 & 20 & 65 & 9 & 10 & 25 & 45 & 17 & 33 & 21\end{array}$

- Astarte triangularian

Myrtea spinifer

Kellia spp.

Tellina crass

- Tellina donacina

Tellina pygmæa

Abra spp.

Gari tellinella

Mactra elliptica

Dosinia spp.

Gafrarium minimum

Venus casina

Chione ovata

Chione fasciata

Paphia rhomboides

Cardium scabrum

Cardium ovale

Hiatella aretica

Gastropoda

a Echinocyamus pusillus

Others

Total (excluding

$$
\text { gastropods) } 236
$$$$
23
$$

1

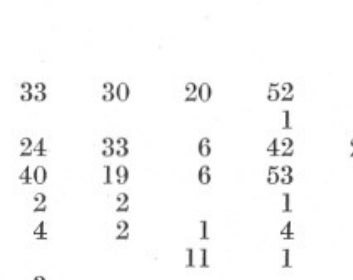

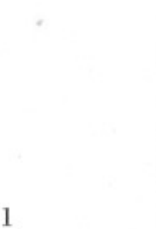

2

2
2
2
1

$\begin{array}{rrrrr}1 & & & 2 \\ & & & & 13 \\ 2 & & 1 & 2 \\ & & 1 & & 1 \\ & & & & 6\end{array}$

9
26
8
1
3

1

52
15
9
14
2
11
11
37

18
1
17
3
1
2
20
9
50
12

15
8
7
1
1
10
6
89
7
1

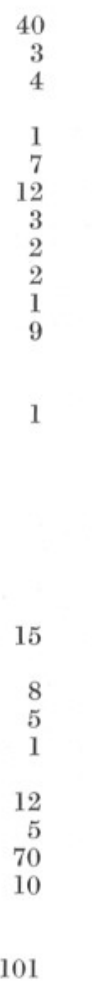

$\begin{array}{rr}39 & 44 \\ 2 & \\ 3 & \\ & \\ 2 & \\ 1 & \\ 4 & \\ 1 & \\ 1 & \\ 2 & \\ 26 & 6\end{array}$

$\begin{array}{rl}44 & 4 \\ 5 & \\ 4 & \\ 5 & \\ 20 & 18 \\ 87 & 9 \\ 5 & \\ 2 & \\ 13 & 17 \\ 68 & 97\end{array}$

$\begin{array}{rrrr}45 & 41 & 46 & 47 \\ 1 & 10 & 1 & \\ 6 & 26 & 1 & 1\end{array}$

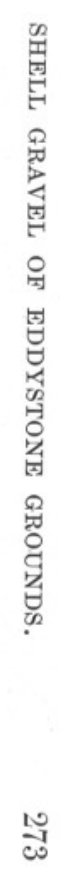




\section{TABLE III.}

\section{List of Species taken on the Sides of the Eddystone Reef,} to the N.W. of the Stone.

\section{PORIFERA.}

Sycon coronatum

Tethya aurantium

Cliona celata

Polymastia mammillaris

Pseudaxinella alleni

Vibulinus stuposus

Myxilla incrustans

Raspailia hispida

Raspailia ramosa

Desmacidon fruticosa

Eurypon clavatum

\section{HYDROZOA.}

Clytea johnstoni

Lafoa dumosa

Lafœa fruticosa

Diphasia attenuata

Diphasia pinaster

Diphasia pinnata

Diphasia tamarisca

Sertularella gayi

Sertularella polyzonias

Abietinaria abietina

Sertularia cupressina

Hydrallmania falcata

Thujaria articulata

Kirchenpaueria pinnata

Plumularia setacea

Plumularia catharina

Nemertesia antennina

Thecocarpus myriophyllium

Aglaophenia tubulifera

\section{ANTHOZOA.}

Alcyonium digitatum

Eunicella verrucosa

Epizoanthus sp.

Gephyropsis dohrni

Caryophyllia smithi

POLYCHATA.

Lepidonotus squamatus

Lagisca extenuata

Scalisetosus assimilis

Typosyllis armillaris

Eunice harassi

Sabella pavonina

Pomatoceros triqueter

Serpula vermicularis

POLYZOA.

Scrupocellaria scruposa

Bicellaria ciliata

Bugula flabellata
Membranipora rosselli

Cellaria fistulosa

Cribrilina figularis

Microporella ciliata

Microporella violacea

Lepralia foliacea

Lepralia pertusa

Chorizopora brongniarti

Smittia trispinosa

Schizoporella linearis

Cellepora pumicosa

Cellepora ramulosa

Crisea cornuta

Crisea denticulata

Crisea eburnea

Diastopora patina

Stomatopora johnstoni

Lichenopora hispida

Domopora truncata

Idmonea serpens

CRUSTACEA.

Scalpellum scalpellum

Verruca strœmia

Balanus spongicola

Bàlanus crenatus

Pyrgoma anglicum

Leucothoë spinicarpa

Galathea strigosa

Porcellana longicornis

Pilumnus hirtellus

Pinnotheres pisum

Pinnotheres? veterum

Eurynome aspera

MOLLUSCA.

Lepidopleurus asellus

Anomia ephippium

Monia patelliformis

Arca tetragona

Modiolus barbatus

Modiolus phaseolinus

Kellia suborbicularis

Hiatella arctica

Emarginula fissura

Calliostoma papillosum

Simnia patula

Erato lævis

ECHINODERMATA.

Antedon bifida

Luidia sarsi

Luidia ciliaris

Porania pulvillus

Marthasterias glacialis 
Ophiothrix fragilis

Ophiactis balli

Psammechinus miliaris

Echinus esculentus

Holothuria forskali

Cucumaria lactea
TUNICATA.

Polycarpa pomaria

Polycarpa fibrosa

Ascidia mentula

Phallusia mammillata

Trididemnum tenerum

\section{TABLE IV.}

\section{List of Species Found on, or in, the Shell Gravel, Polyzoa and Nemertini Excluded. \\ $x$ denotes presence in one or more samples. \\ ken once only.}

\section{HYDROZOA}

Sertularella gayi

Abietinaria abietina

* Plumularia setacea

Nemertesia antennina

ANTHOZOA.

Sarcodictyon catenata

*Alcyonium digitatum

Epizoanthus incrustatus

Tlyanthus mitchelli

*Caryophyllia smithi

\section{POLYCHATA.}

Polygordius lacteus

"Eunoë nodosa

*Lagisca extenuata

*Sthenelais bos

Mystides limbata

Syllis spp.

Nephthys hombergi

Prægeria remots

Glycera lapidum

Glycera gigantea

Glycera sp.

*Eunice harassi

Onuphis conchylega

Hyalinoscia tubicola

Hyalincecia bilineat

Lumbriconereis

impatiens

* Aricia sp.

*Polydora sp.

Owenia fusiformis

* Petta pusilla

Lanice conchylega

Terebellides stroemi

* Serpula vermicularis

- Hydroides norvegica

"Pomatoceros triquete

Maldanids

\section{GEPHYREA.}

*Phascolosoma vulgare

CRUSTACEA

*Pyrgoma anglicum

*Sacculina sp.

*Nannastacus sp.

Conilera eylindracea

*Lyssianassidæe

Ampelisca brevicornis

Ampelisca tenuicornis

Ampelisca spinipes

Urothoë marina

*Leucothoë spinicarpa

* Ceradocus semiserratus

Mora othonis

Lembos longines

*Leptocheirus

hirsutimanus

*Megamphopus cornutus

*Phtisica marina

*Crangon allmani

Galathea dispersa

*Galathea strigosa

Representative Number of gravel.

$\begin{array}{ccc}3.0- & 2 \cdot 0- \\ 2 \cdot 0 & 1.0 & <1.0\end{array}$

Porcellana longicornis

Upogebia deltaura

* Eupagurus cuanensis

*Anapagurus levis

Portunus pusillus

Portunus depurator

Atelecyclus

septemdentatus

Ebalia tuberosa

Ebalia tumefacta

\section{MOLLUSCA.}

Nucula nucleus

Nucula radiata

Glycymeris glycymeris

Modiolus phaseolinus

Chlamys varia

*Chlamys tigerina

Pseudamussium simil is

* Lima subauriculata

Astarte sulcata

Astarte triangularis

*Kellfa suborbicularis

Tellina crassa

Tellina donacina

Tellina pygmma

* Abra prismatica

* Abra alba

Gari tellineila

* Gari costulata

Gafrarium minimum

Venus casina

Chione ovata

Chione fasciata

Paphia rhomboides

Cardium scabrum

Cardium scabrum

Cardium ovale

Lrevicardium crassum

Psammsolen candidus

* Emarginula fissura

* Mangelia linearis

* Calliostoma papillosum

Trivia europœea

Natica alderi

*Turritella communis

* Scaphander lignarius

-Doto fragilis

ECHLNODERMATA.

* Astropecten irregularis

- Auidia ciliaris

Ophiothrix fragilis

Ophiura texturata

Opiura affinis

Echinocyamus pusillus

Spatangus purpureus

Fchinocar purpu

flavescens

Cucumaria hyndmani

\section{TUNICATA.}

*Eugyra arenosa

* Polycarpa fibrosa

Representative Number of gravel.
$>3 \cdot 0 \begin{array}{ll}3 \cdot 0- & 2 \cdot 0 \\ 2 \cdot 0 & 1 \cdot 0\end{array}$
$<1 \cdot 0$

$x+\frac{1}{x}$ 
STATIONS NORTH-EAST OF EDDYSTONE. No. 38. 1100 yards N.E. Oct. 29th, 1931. Per 1000 c.e. of gravel.

Glycymeris glycymeris

Astarte triangularis

Tellina crassa

Gafrarium minimum

Chione ovata

Echinocyamus pusillus

Amphipod (indet.)

Polygordius SD.

Syllid sp.

Mystides limbata

Glycera lapidum

Amphioxus lanceolatus

No, 36. 2600 yards N.E. Oct, 15th, 1931. Per 1000 c.c. of gravel.

Nucula radiata

Glycymeris glycymeris

Astarte triangularis

Tellina crassa

Tellina pygmæa

Venus casina

Chione fasciata

Echinocyamus pusillus

Ampelisca brevicornis

Polygordius sp.

Lanice conchylega

Terebellid tube

No. 35. 3500 yards N.F. Oct. 15th, 1931. Per 1000 c.c. of gravel.

Nucula radiata

Modiolus phaseolinus

Tellina pygmrea

Chione ovata

Ampelisca brevicornis

Urothoë marina

Glycera lapidum

Lanice conchylega

Terebellides stromi

Owenia tubes

STATIONS EAST OF EDDYSTONE.

No. 33. 1075 yards E. Oct. 1st, 1931. Per 1000 c.c. of gravel.

Lima subauriculata

Astarte triangularis

Tellina pygmæa

Chione fasciata

Paphia rhomboides

Echinocyamus pusillus

Polygordius sp.

Syllis sp.

Glycera lapidum

Mystides limbat

Sarcodictyon catenata

. 1000 c.c. of gravel.

Nucula radiata

Glycymeris glycymeris

Astarte triangularis

Gafrarium minimum

Chione fasciata

Echinocyamus pusillus

2. pieces
Urothoe marina

Syllis sp.

Glycera lapidum

Mystides limbata

Hyalinoecia sp.

Aricia sp.

Amphioxus lanceolatus

No. 34. 2525 yards E. Oct. 1st, 1931 Per 1000 c.c. of gravel.

Astarte triangularis

Tellina pygmæa

Abra abra

Venus casina

Natica alderi

Echinocyamus pusillus

Ampelisca brevicornis

Ampelisca tenuicornis

Polygordius sp.

Glycera lapidum

Prægeria remota

Terebellid sp.

Owenia fusiformis

Maldanids

Owenia tubes

Amphioxus lanceolatus

STATIONS IN THE SOUTH-EAST QUARTER OF THE EDDYSTONE.

No. 39. 1075 yards E.S.E. Oct. 29th. 1931. Per 1000 c.c. of gravel.

Echinocyamus pusillus

Ampelisca spinipes

1

Polygordius sp.

Glycera lapidum

Hyalinoecia sp.

Eunoë nodoss

Amphioxus lanceolatus

No. 40. 1090 yards S. by F. Oet. 29th, 1931. Per 1000 c.c. of gravel.

Astarte triangularis

Chione fasciata

Echinocyamus pusillus

Nephthys sp. (juv.)

Maldanid

No. 44. 1670 yards S.E. Dec. 11th, 1931. Per 1000 c.c. of gravel.

Glycymeris glycymeris

Astarte triangularis

Chione ovata

Anapagurus lævis

Galathea sp. (juv.)

Polygordius sp.

Syllids

Glycera lapidum

Pregeria remota

Maldanid

Nemertini

Micrura sp.
1
1

1

1

1 
No. 45. 2000 yards S.E. 1 S. Dec. 11th, 1931. Per 1000 c.c. of gravel.

Astarte triangularis

Tellina pygmæa

Gafrarium minimum

Chione ovata

Chione fasciata

Echinocyamus pusillus

Ampelisca spinipes

Ebalia sp. (juv.)

Syllids

Phyllodocids

Glycera lapidum

Lumbriconereis impatiens

Amphioxus lanceolatus

STATIONS SOUTH-WEST OF EDDYSTONE

No. 41. 1850 yards S.W 1 S. Dec. 9th, 1931. Per $1000 \mathrm{c.c}$. of gravel.

Astarte triangularis

Nucula sp.

Gafrarium minimum

Chione ovata

Chione fasciata

Cardium ovale

Echinocyamus pusillus

Ophiura? affinis (juv.)

Polygordius sp.

Syllis vittats

Syllids

Phyllodocids (juv.)

Lumbriconereis sp.

Glycera lapidum

Prægeria remota

Polychreta indet.

Amphioxus lanceolatus

11

1

No, 46. 2600 yards SW. Dec. 11th, 1931. Per 1000 c.c. of gravel.

Nucula sp.

Echinocyamus pusillus

Spirontocaris cranchi

Polygordius sp.

Glycera sp.

Glycera lapidum

Phyllodocids

Owenia tubes

No. 47. 3000 yards S.W. Dec. 11th, 1931. Per 1000 c.c. of gravel.

Paphia rhomboides

Echinocyamus pusillus

Conilera cylindracea

Cheirocratus sundevalli

Polygordius sp.

Polynoid

Lumbriconereis impatiens

Glycera lapidum

Nephthys sp.

Hyalinœecia bilineata

Arenicola sp.

Sabellids (juv.)

Pomatoceros triqueter tubes

Maldanids

Owenia tubes

Nemertesia antennina
STATIONS WEST OF EDDYSTONE.

No. 421725 yards W. Dec. 11th, 1931. Per 1000 c.c. of gravel.

Nucula sp.

Glycymeris glycymeris

Astarte triangularis

Tellina pygmæa

Gafrarium minimum

Chione ovata

Echinocyamus pusillus

Ophiuroid sp.

Ebalia sp. (juv.)

Megamphopus cornatus

Lembos longipes

Polygordius sp.

Syllis sp.

Glycera sp.

Glycera lapidum

Lumbriconereis impatiens

Lumbriconereis sp.

Mystides limbata

Sabellid sp. (juv.)

Maldanids

Micrura sp.

Micrura sp. (juv.)

2

No. 43. 2350 yards W. Dec. 11th, 1931. Per 1000 c.c. of gravel.

Chione fasciata

Gnathia maxillaris

Megamphopus cornutus

Polynoid

Syllids

Phyllodocids (juv.)

Glycera lapidum

Lumbriconereis impatiens

Mystides limbata

Ephesia gracilis

Maldanids

Terebellid tubes

Owenia tubes

Iepralia foliacea

Epizoanthus incrustatus

1

1

$\frac{1}{2}$

3

4
1

1

1

2

pieces

4 colonies

STATIONS NORTH-WEST OF EDDYSTONE ${ }_{1}^{1} \mathrm{~m}^{2}$ Grab samples

No. 21. 1320 yards N.W. by N. May 20th, 1931. Per 1000 c.c. of gravel.

Nucula radiata

Glycymeris glycymeris

Astarte triangularis

cata $\quad 0.5$

Gafrarium minimum $\quad 2 \cdot 0$

Venus casina $\quad 1 \cdot 0$

Chione ovata $\quad 0.5$

Chione fasciata

Ophiuroid (juv.)

Echinocyamus pusillus $\quad 17 \cdot 5$

Mæra othonis 0.5

Ceradocus semiserratus $\quad 0.5$

Syllis cormuta $\longrightarrow \quad 0.5$

Eusyllis sp. $\quad 0.5$

Glycera lapidum $\quad 0.5$

Pregeria remota 3.0

Nemertini $\quad 1.5$

Sarcodictyon catenata 1 colony 
No, 23, 1920 yards N.W.tN. May 20th, 1931. Per 1000 c.c. of gravel.

Astarte triangularis

Astarte sulcata

Tellina pygmea

Pseudamussium similis

Chione ovata

Echinocyamus pusillus

Prægeria remota

Syllids

Onuphis conchylega

Onuphis tube

\section{STATIONS IN THE NORTH-WEST}

QUARTER OF EDDYSTONE.

No. 19. 820 yards N.N.W. May 20th, 1931. Per 1000 c.c. of gravel.

Glycymeris glycymeris

Astarte triangularis

Gari tellinella

Gari costulata

Gafrarium minimum

Venus casina

Chione ovata

Cardium ovale

Paphia rhomboides

Echinocyamus pusillus

Ampelisca spinipes

1
1
2
1
2
33
2
2
1
2
1

Polygordius sp.

Lumbriconereis impatiens

Onuphis conchylega

Glycera sp.

Micrura sp.

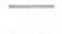

Phascolosoma vulgare with

Loxosoma phascolosomatum

No. 28. 1010 yards N.N.W. July 23rd, 1931. Per 1000 c.c. of gravel.

Glycymeris glycymeris

Astarte triangularis

Gafrarium minimum

Chione fasciata

Echinocyamus pusillu

Spatangus purpureus

Cucumaria sp. (juv.)

Glycera sp.

Hyalinoecia sp.

No. 22. 1720 yards N.W. by N. May 20th, 1931 . Per 1000 c.c. of gravel.

Glycymeris glycymeris

Astarte triangularis

Astarte sulcata (juv,)

Gafrarium minimum

Chione ovata

Cardium scabrum

Echinocyamus pusillus

Ophiura sp. (juv:)

Ampelisca spinipes

Lyssianassa sp.

Syllis cornuta

Goniada sp.

Micrura sp.
STATIONS IN THE NORTH-WEST QUARTER OF EDDYSTONE.

No. 30. 1760 yards N.W. by N.1N. Sept. 10th, 1931. Per 1000 e.c. of gravel.

Glycymeris glycymeris

Astarte triangularis

Gafrarium minimum

Gari tellinella

Echinocyamus pusillus

Polygordius sp.

Glycera lapidum

Glycera sp.

Syllid

Sarcodictyon catenata

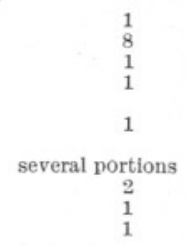

1 piece
No. 29. 2000 yards N.N.W. Sept. 3rd, 1931. Per 1000 c.c. of gravel.

Astarte triangularis

Chione fasciata

Lævicardium crassum

Echinocyamus pusillus

Echinocardium flavescens

Ampelisca spinipes

Polygordius sp.

Glycera lapidum

No. 20. 2150 yards N.W.3. M. May 20th, 1931. Per 1000 c.c. of gravel.

Astarte triangularis

Astarte sulcata (juv.)

Tellina donacina

Gafrarium minimum

Venus casina

Chione ovata
Chione fasciat

Cardium ovale

Echinocyamus pusillus

Ophiuroid sp. (juv,)

Mæra sp.

Urothoë $\mathrm{sp}$.

Ampelisca spinipes

Glycera lapidum

Onuphis conchylega

Hyalinœecia bilineata

Nemertesia antennina with Doris spawn

No. 27. 2175 yards N.N.W. July 23rd, 1931. Per 1000 c.c. of gravel.

Glycymeris glycymeris

Pseudamussium similis

Astarte triangularis

Gafrarium minimum

Chione ovata

Venus casina

Natica alderi

Echinocyamus pusillus

Ophiothrix fragilis (juv,

Conilera cylindracea

Ampelisca spinipes

Eupagurus cuanensis

Portunus pusillus

Prægeria remoto

Onuphis conchylega

Glycera lapidum

Lumbriconereis impatiens

Syllid

Maldanid

Hyalinoscia tubes

Onuphis tubes

Nemertini 